\title{
The size distribution and origin of elements bound to ambient particles: a case study of a Polish urban area
}

\author{
Wioletta Rogula-Kozlowska • Grzegorz Majewski • \\ Piotr Oskar Czechowski
}

Received: 9 October 2014 / Accepted: 18 March 2015 /Published online: 11 April 2015

(C) The Author(s) 2015. This article is published with open access at Springerlink.com

\begin{abstract}
Ambient particulate matter (PM) was sampled in Zabrze (southern Poland) in the heating period of 2009. It was investigated for distribution of its mass and of the masses of its 18 component elements $(\mathrm{S}, \mathrm{Cl}$, $\mathrm{K}, \mathrm{Ca}, \mathrm{Cr}, \mathrm{Mn}, \mathrm{Fe}, \mathrm{Ni}, \mathrm{Cu}, \mathrm{Zn}, \mathrm{Ge}, \mathrm{As}, \mathrm{Br}, \mathrm{Sr}, \mathrm{Cd}, \mathrm{Sb}, \mathrm{Ba}$, and $\mathrm{Pb}$ ) among $13 \mathrm{PM}$ size fractions. In the paper, the distribution modality of and the correlations between the ambient concentrations of these elements are discussed and interpreted in terms of the source apportionment of $\mathrm{PM}$ emissions. By weight, $\mathrm{S}, \mathrm{Cl}, \mathrm{K}, \mathrm{Ca}, \mathrm{Cr}, \mathrm{Mn}, \mathrm{Fe}, \mathrm{Ni}$, $\mathrm{Cu}, \mathrm{Zn}, \mathrm{Ge}, \mathrm{As}, \mathrm{Br}, \mathrm{Sr}, \mathrm{Cd}, \mathrm{Sb}, \mathrm{Ba}$, and $\mathrm{Pb}$ were $10 \%$ of coarse and $9 \%$ of ultrafine particles. The collective mass of these elements was no more than $3.5 \%$ of the mass of the particles with the aerodynamic diameter $D_{\mathrm{p}}$ between 0.4 and $1.0 \mu \mathrm{m}\left(\mathrm{PM}_{0.4-1}\right)$, whose ambient mass concentration was the highest. The PM mass size distribution for the sampling period is bimodal; it has the accumulation and coarse modes. The coarse particles were probably of the mineral/soil origin (characteristic elements: $\mathrm{Ca}, \mathrm{Fe}$, $\mathrm{Sr}$, and $\mathrm{Ba}$ ), being re-suspended polluted soil or road dust (characteristic elements: $\mathrm{Ca}, \mathrm{Fe}, \mathrm{Sr}, \mathrm{Ba}, \mathrm{S}, \mathrm{K}, \mathrm{Cr}, \mathrm{Cu}, \mathrm{Zn}$,
\end{abstract}

W. Rogula-Kozłowska $(\bowtie)$

Institute of Environmental Engineering, Polish Academy of

Sciences, 34 M. Skłodowska-Curie St., 41-819 Zabrze,

Poland

e-mail: wioletta@ipis.zabrze.pl

G. Majewski

Division of Meteorology and Climatology, Warsaw University of Life Sciences, 166 Nowoursynowska St., 02-776 Warszawa, Poland

P. O. Czechowski

Information Systems Department, Gdynia Maritime

University, 83, Morska St., 81-225 Gdynia, Poland
$\mathrm{Br}, \mathrm{Sb}, \mathrm{Pb}$ ). The maxima of the density functions (modes) of the concentration distributions with respect to particle size of PM-bound $\mathrm{S}, \mathrm{Cl}, \mathrm{K}, \mathrm{Cu}, \mathrm{Zn}, \mathrm{Ge}, \mathrm{Br}, \mathrm{Cd}, \mathrm{Sb}$, and $\mathrm{Pb}$ within the $D_{\mathrm{p}}$ interval from 0.108 to $1.6 \mu \mathrm{m}$ (accumulation PM particles) indicate the emissions from furnaces and road traffic. The distributions of PM-bound As, $\mathrm{Mn}, \mathrm{Ba}$, and $\mathrm{Sr}$ concentrations have their modes within $D_{\mathrm{p}} \leq 0.108 \mu \mathrm{m}$ (nucleation PM particles), indicating the emissions from high-temperature processes (industrial sources or car engines). In this work, principal component analysis (PCA) is applied separately to each of the 13 fraction-related sets of the concentrations of the 18 PM-bound elements, and further, the fractions are grouped by their origin using cluster analysis (CA) applied to the 13 fraction-related first principal components (PC1). Four distinct groups of the PM fractions are identified: ( $\left.\mathrm{PM}_{1.6-2.5}, \mathrm{PM}_{2.5-4.4}\right),\left(\mathrm{PM}_{0.03-0.06}, \mathrm{PM}_{0.108-}\right.$ 0.17), $\left(\mathrm{PM}_{0.06-0.108}, \mathrm{PM}_{0.17-0.26}, \mathrm{PM}_{0.26-0.4}, \mathrm{PM}_{0.4-0.65}\right.$, $\left.\mathrm{PM}_{0.65-1}, \mathrm{PM}_{1-1.6}\right)$, and $\left(\mathrm{PM}_{4.4-6.8}, \mathrm{PM}_{6.8-10}, \mathrm{PM}_{>10}\right)$. The PM sources attributed to these groups by using PCA followed by CA are roughly the same as the sources from the apportionment done by analyzing the modality of the mass size distributions.

Keywords Ultrafine ambient aerosol · Particulate matter - Toxic metals - Mass size distribution · PCA . Cluster analysis

\section{Introduction}

Airborne particles can absorb practically any air contaminant. This capability of particulate matter (PM), due 
to its physicochemical properties, makes PM a great threat to human health, especially in big cities (Molina and Molina 2004; Lee and Lee 2008; Kong et al. 2012). The dependence between the ambient concentrations of fine $\mathrm{PM}\left(\mathrm{PM}_{1}\right.$ or $\mathrm{PM}_{2.5}$, particles with the aerodynamic diameter $D_{\mathrm{p}} \leq 1$ or $2.5 \mu \mathrm{m}$, respectively) and the PM health effects is well-studied and obvious: elevation of the PM concentrations increases mortality and morbidity in exposed populations (Pope et al. 2002; LópezVillarrubia et al. 2012). However, the exact mechanisms of the PM toxic action on living organisms remain unknown (Dreher 2000; Harrison and Yin 2000). The PM toxicity derives rather from the synergistic effects of physicochemical properties of the particles and the environmental circumstances (Saldiva et al. 2002; Wellenius et al. 2003); nevertheless, the elemental content of PM is proved to decide on the potential health effects of PM.

The hazard from the PM-bound, so called, toxic or heavy metals is partially due to the chemical forms of their occurrence (Costa and Dreher 1997; Na and Cocker 2009; Daher et al. 2012; Rogula-Kozłowska et al. 2013a). In general, being easily water-soluble, they become bioavailable after entering water or soil.

Table 1 presents the elemental composition of various PM fractions at a number of sites in Europe. The PM component concentrations are averaged over various periods of the last decade, and come from urban or urban background sites.

Usually, the PM investigations focus on the elemental composition of $\mathrm{PM}_{2.5}$ or $\mathrm{PM}_{10}\left(D_{\mathrm{p}} \leq 2.5\right.$ or $\left.10 \mu \mathrm{m}\right)$. While such works are quite numerous (not only in Europe, also in Asia and the Americas), the elemental composition of the submicron $\left(\mathrm{PM}_{1}\right)$ and ultrafine $\left(\mathrm{PM}_{0.1}\right) \mathrm{PM}$ has not been investigated very intensely, neither has the distribution of the PM-bound element masses among the PM fractions (Sanderson et al. 2014). However, these few existing studies prove that most of the mass of the PM-bound toxic metals accumulates in the finest particles (e.g., Birmili et al. 2006; Arhami et al. 2009; Daher et al. 2014; Rogula-Kozłowska et al. 2013b, c; Table 1). In fact, the finer PM particles are, the more they are toxic. It combines with the ability of the inhaled finest particles to reach the pulmonary alveoli, where the absorption efficiency for elements is 60-80 \% (Infante and Acosta 1990; Pope and Dockery 2006). Such particles make usually the main part of the PM mass in urbanized areas, also in Poland (Klejnowski et al. 2007, 2012). Therefore, the analysis of the elemental composition of the finest PM particles provides essential information on the PM toxicity (Almeida et al. 2007; Kumar et al. 2008; Daher et al. 2012, 2014).

In a heating season, in most (European) urban areas, the combustion of various fuels for heating keeps the PM concentrations high (Table 1). In Poland, especially in its southern part, in winter (January and February), episodes of smog and extremely high PM concentrations are frequent; they are due to the municipal emissions and specific weather conditions (Pastuszka et al. 2003, 2010; Juda-Rezler et al. 2011; Klejnowski et al. 2007, 2012; Lewandowska and Falkowska 2013; Rogula-Kozłowska et al. 2013b, 2014; NidzgorskaLencewicz and Czarnecka 2014). For the purposes of this study, PM was sampled in Zabrze, a city in southern Poland, in autumn and winter (September-December of 2009), when all the possible emission sources are active. The emissions from traffic, industry, and re-suspended dust are present in Zabrze during the whole year; the municipal emissions (fossil fuel combustion) grow significantly in late autumn and early winter, but in September-December the smog episodes and very high municipal emissions, capable of overshadowing the contributions of other sources to the PM elemental composition and concentrations, almost certainly do not occur. Such a selection of the sampling period favored the determinations of the mass distributions of the 18 PM-bound elements with respect to particle size and of the correlations between the PM-bound elements.

The aim of the work is to give some insight into the origin of particular PM fractions in an urban area. This is achieved by analyzing the modalities of the mass distributions of PM and $18 \mathrm{PM}$-bound elements $(\mathrm{S}, \mathrm{Cl}, \mathrm{K}, \mathrm{Ca}$, $\mathrm{Cr}, \mathrm{Mn}, \mathrm{Fe}, \mathrm{Ni}, \mathrm{Cu}, \mathrm{Zn}, \mathrm{Ge}, \mathrm{As}, \mathrm{Br}, \mathrm{Sr}, \mathrm{Cd}, \mathrm{Sb}, \mathrm{Ba}$, and $\mathrm{Pb}$ ) among $13 \mathrm{PM}$ size fractions and application of cluster analysis (CA) to the first principal components (PC1) found for 13 fraction-related sets of concentrations of these elements using principal component analysis (PCA). The results are discussed and interpreted in terms of the source apportionment of PM emissions.

\section{Materials and methods}

PM was sampled in Zabrze (southern Poland, Silesia Province), between 5 September and 25 December of 2009, at an urban background site (EC 2008; Fig. 1). The sampling point neighborhood consisted of a trunk road (approx. $500 \mathrm{~m}$ to the north), blocks of flats and residential houses (to the east), Zabrze city center with 


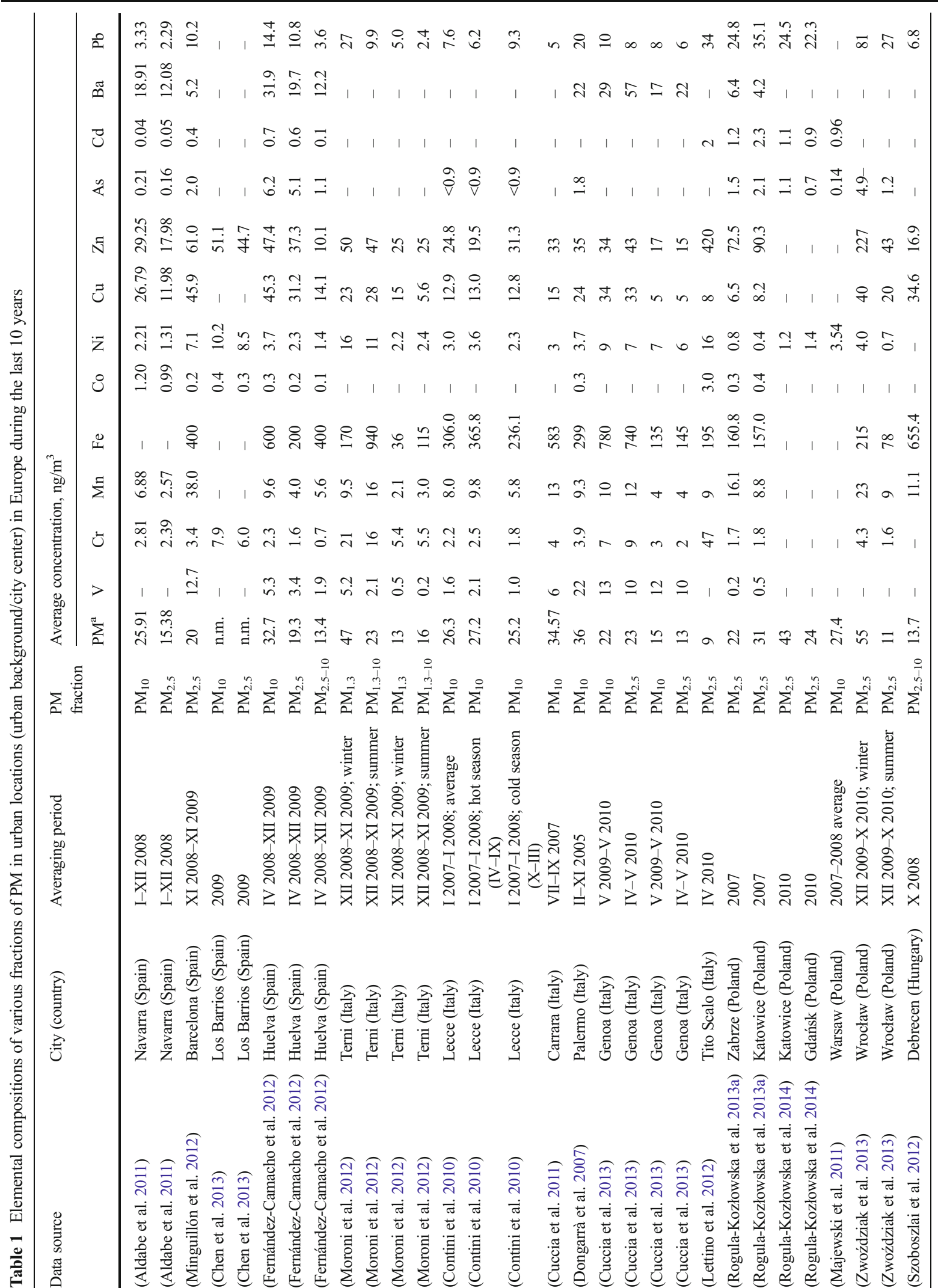




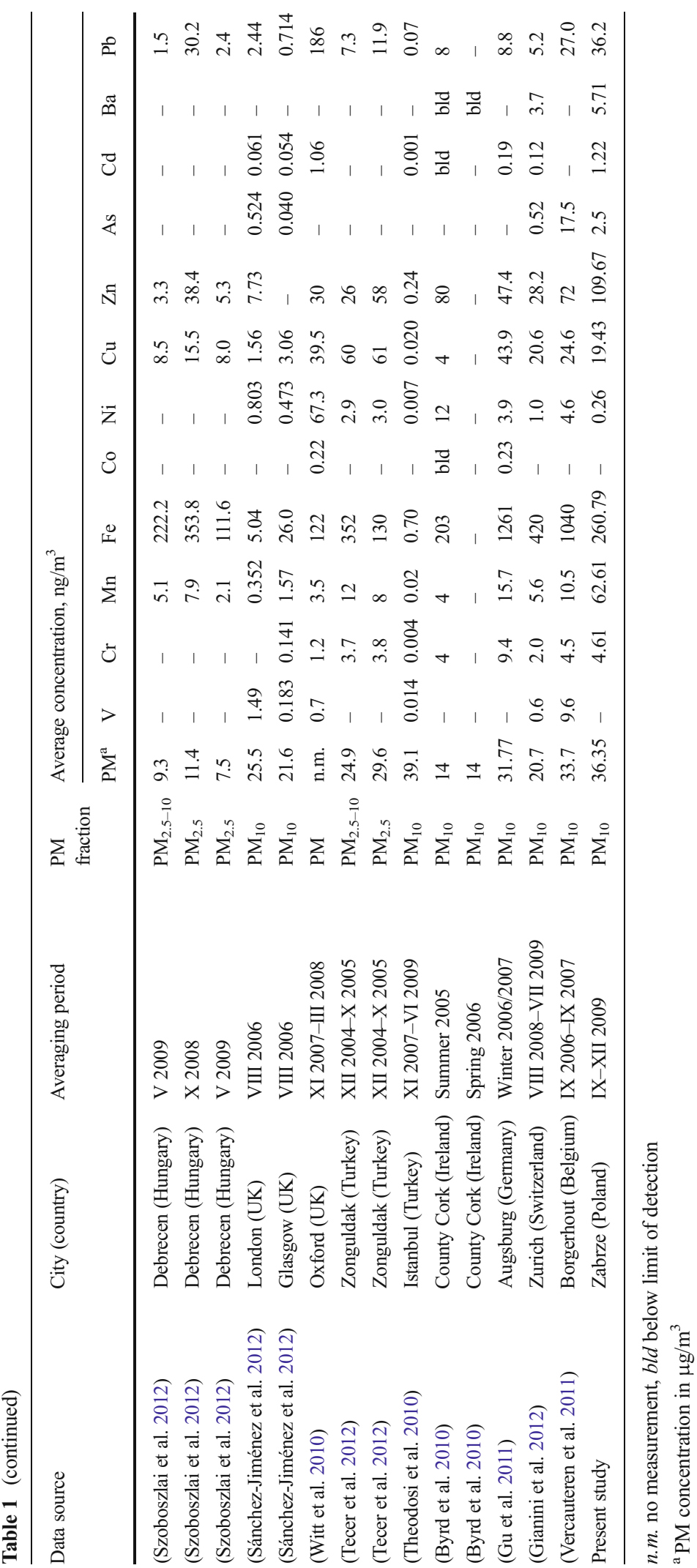




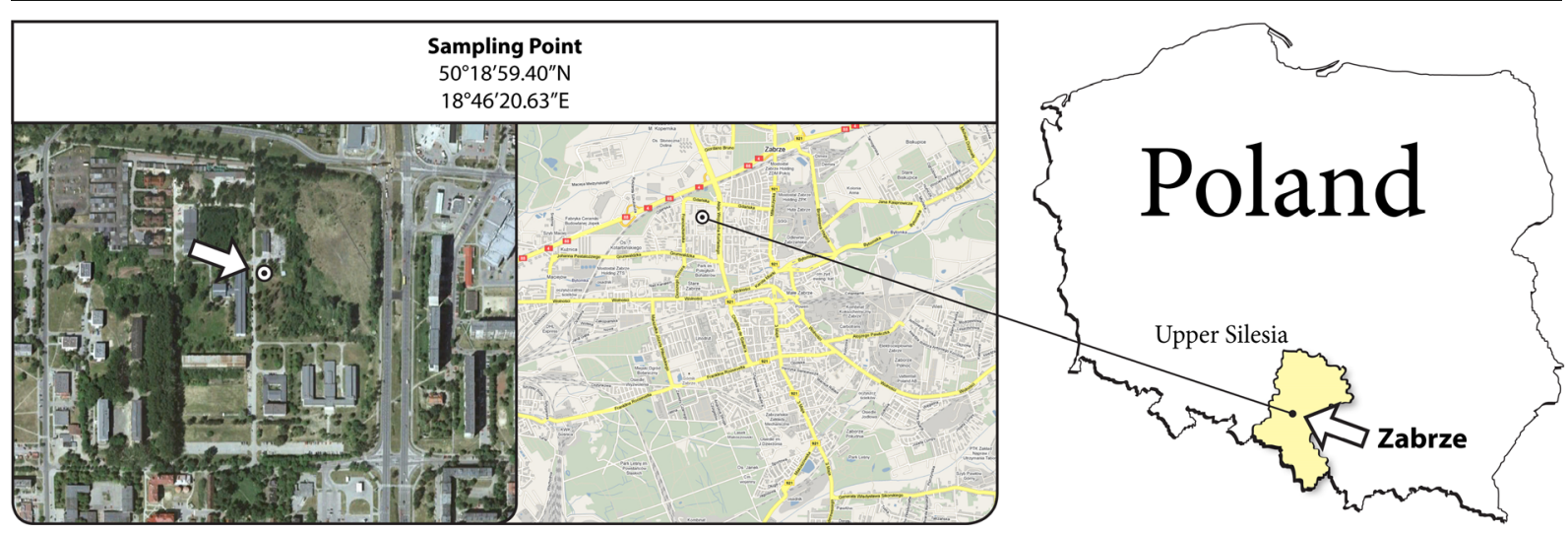

Fig. 1 The sampling point location

residential and commercial housing (to the south and south-east), and blocks of flats and allotments (to the west). The surrounding houses were either connected to the district heating network or heated with local coal-, gas-, or electricity-powered boilers.

The city of Zabrze $\left(80.5 \mathrm{~km}^{2}, 2363\right.$ person $\left./ \mathrm{km}^{2}\right)$ is located in the Upper Silesia Agglomeration. In Zabrze, the degradation of the environment related to hard coal excavation and production of coal-derivatives started in the early nineteenth century (a cokery built in Zabrze in 1884 still works, some other, more ancient, were shut down in the late twentieth century). The problem of the environmental pollution in the area was considered serious late, in the 1950s (Pastuszka 1997), and even this did not stem the further environmental degradation, most effective during the 1960 s and 1970 s. In the 1970s, the dust deposition in Zabrze exceeded $2000 \mathrm{~g} /$ $\left(\mathrm{m}^{2} \cdot\right.$ year $)$; in the 1980s, the lead deposition reached $3 \mathrm{~g} /$ $\left(\mathrm{m}^{2}\right.$.year) in the Zabrze surroundings (RogulaKozłowska et al. 2012; references therein). Although the industrial emissions have been seriously reduced during the last 30 years, the PM concentrations within the area are still one of the highest in the EU (Table 1), mainly because of dense and obsolete housing, where poor quality hard coal, scrap, and household garbage are burnt in inefficient ovens to warm flats.

The PM samples were collected with a 13-stage lowpressure cascade impactor (DLPI, Dekati). The impactor catches particles of the aerodynamic diameter $\left(D_{\mathrm{p}}\right)$ from 0.03 to $40 \mu \mathrm{m}$ at the flow rate of $1.8 \mathrm{~m}^{3} / \mathrm{h}$ (pump: Sogevac SV/25). It splits PM into $13 \mathrm{PM}$ fractions: $\mathrm{PM}_{0.03-0.06}, \mathrm{PM}_{0.06-0.108}, \mathrm{PM}_{0.108-0.17}, \mathrm{PM}_{0.17-0.26}$, $\mathrm{PM}_{0.26-0.4}, \mathrm{PM}_{0.4-0.65}, \mathrm{PM}_{0.65-1.0}, \mathrm{PM}_{1.0-1.6}, \mathrm{PM}_{1.6-2.5}$, $\mathrm{PM}_{2.5-4.4}, \mathrm{PM}_{4.4-6.8}, \mathrm{PM}_{6.8-10.0}$, and $\mathrm{PM}_{10.0-40} . \mathrm{PM}_{\mathrm{x}-\mathrm{y}}$ denotes the PM fraction whose particles have their $D_{\mathrm{p}}$ in the interval $[\mathrm{x}, \mathrm{y}] ; D_{\mathrm{p}}=0.03 \mu \mathrm{m}$ in $\mathrm{PM}_{0.03-0.06}$ and $D_{\mathrm{p}}=$ $40 \mu \mathrm{m}$ in $\mathrm{PM}_{10.0-40}$ are the $D_{\mathrm{p}}$ limits for particles possible to sample (Hinds 1998). $\mathrm{PM}_{\mathrm{x}}$ stands for $\mathrm{PM}_{0.03-\mathrm{x}}$. A single (continuous) sample-taking lasted 8-10 days. Altogether, 12 sample-takings were done that covered about $90 \%$ of the whole sampling period.

The masses of PM on the substrates were determined gravimetrically, according to the European standards (PN-EN 12341:2006a; PN-EN 12341:2006b). Before each weighing of the substrates, before and after their exposure, they were conditioned for $48 \mathrm{~h}$ in the weighing room (air temperature $20 \pm 1^{\circ} \mathrm{C}$, relative air humidity 50 $\pm 5 \% \mathrm{RH})$. A concentration of a PM fraction was calculated from its mass on a substrate and from the flow rate.

The PM samples (156 in total) were analyzed for their elemental content by means of energy dispersive X-ray fluorescence (EDXRF) on a PANalytical Epsilon 5. The apparatus was equipped with an X-ray tube with a side window (nitrogen-cooled, gadolinium anode, working range $25-100 \mathrm{kV}, 150-\mu \mathrm{m}$ beryllium window), a system of nine secondary targets $(\mathrm{Al}, \mathrm{Ti}, \mathrm{Fe}, \mathrm{Ge}, \mathrm{Zr}$, $\mathrm{Mo}, \mathrm{Ag}, \mathrm{Ce}_{2} \mathrm{O}_{3}, \mathrm{Al}_{2} \mathrm{O}_{3}$ ), and a $\mathrm{Ge}(\mathrm{Li})$ detector (resolution $140 \mathrm{eV}$, energy range $0.7-100 \mathrm{keV}$, working surface $30 \mathrm{~mm}^{2}, 8-\mu \mathrm{m}$ beryllium window).

The measurements were conducted under vacuum. The analysis, including the run of the whole program of the changes of targets and X-ray tube settings $(25 \mathrm{keV}$ and $25 \mathrm{~mA}$ for $\mathrm{Al}, 40 \mathrm{keV}$ and $15 \mathrm{~mA}$ for Ti, $40 \mathrm{keV}$ and $15 \mathrm{~mA}$ for Fe, $75 \mathrm{keV}$ and $8 \mathrm{~mA}$ for $\mathrm{Ge}, 100 \mathrm{keV}$ and $6 \mathrm{~mA}$ for $\mathrm{Zr}, 100 \mathrm{keV}$ and $6 \mathrm{~mA}$ for $\mathrm{Al}_{2} \mathrm{O}_{3}$ ) lasted $2400 \mathrm{~s}$. The concentrations of particular analytes were derived by comparing the results with the calibration curves. The curves were determined by measuring thinlayer standards (Micromatter, Inc.) and corrected for possible matrix effects. 
The NIST standard reference material (SRM2873) was measured weekly. The recovery of each element was between $84 \%(\mathrm{As})$ and $116 \%(\mathrm{~Pb})$ of the certified value. Three blanks (aluminum substrates) were used to determine the detection limits for the procedure. Each blank underwent the entire EDXRF procedure devised for a regular sample 30 times; a detection limit for an element was the standard deviation from the 90 results obtained for this element. The detection limits were between $0.3(\mathrm{~Pb})$ and $11.6(\mathrm{As}) \mathrm{ng} / \mathrm{cm}^{2}$.

\section{Results and discussion}

Table 2 shows the average (over the measuring period) ambient concentrations of 13 PM fractions and of the fraction-bound elements. The average $\mathrm{PM}_{10}$ concentration, $36.3 \mu \mathrm{g} / \mathrm{m}^{3}$, is comparable with or slightly higher than the $\mathrm{PM}_{10}$ concentrations in other European urban locations in winter (Table 1). In Zabrze and other Upper Silesian cities, the PM concentrations can be significantly higher at the turn of the year and in January-February (Pastuszka et al. 2010; Rogula-Kozłowska et al. 2014).

Among all the fractions, $\mathrm{PM}_{0.4-1}$ had the highest concentrations, both those averaged over the measuring period and those from particular measurements. Like $\mathrm{PM}_{0.4-1}$ among the fractions, the total of the $18 \mathrm{PM}_{0.4}$ 1-bound elements had the highest mass concentration among the thirteen fraction-bound 18 element totals. Somewhat lower, but also high, was this concentration for $\mathrm{PM}_{1-1.6}$. The differences between minimum and maximum of the collective ambient concentrations of the 18 elements in the measuring period are the largest for $\mathrm{PM}_{0.4-0.65}, \mathrm{PM}_{0.65-1}$, and $\mathrm{PM}_{1-1.6}$, the sub-fractions of $\mathrm{PM}_{0.4-1.6}$, and the smallest for $\mathrm{PM}_{0.03-0.06}, \mathrm{PM}_{0.06-}$ 0.108 , and $\mathrm{PM}_{0.108-0.17}$, the sub-fractions of $\mathrm{PM}_{0.03-0.17}$ (Fig. 2). For the latter, the finest, these concentrations are very low - the measuring period maximum for $\mathrm{PM}_{0.06-0.108}$ is 19 times lower than for $\mathrm{PM}_{0.65-1}$. Instead, the proportions of the measuring period maximum to minimum of these concentrations for all the subfractions of both $\mathrm{PM}_{0.4-1.6}$ and $\mathrm{PM}_{0.03-0.17}$ are close, about 4-5; they are about 3 for $\mathrm{PM}_{4.4-6.8}, \mathrm{PM}_{6.8-10}$, and $\mathrm{PM}_{>10}$, contained in $\mathrm{PM}_{>4.4}$. The measuring period averages of the 18 element total concentrations for the sub-fractions of $\mathrm{PM}_{>4.4}$ are significantly higher than those for the smallest particles (Table 2), but they differ less between the particular measurements. For example, the maximum to minimum proportions of the 18 element total concentrations for $\mathrm{PM}_{1.6-2.5}$ and $\mathrm{PM}_{2.5-}$ 4.4 are low, about 2 and 3; for $\mathrm{PM}_{0.17-0.26}$ and $\mathrm{PM}_{0.26-0.4}$ they are about 5 and 6 , respectively (Fig. 2).

By weight, the shares of the 18 element totals in $\mathrm{PM}_{1.6-40}$ and in $\mathrm{PM}_{0.03-0.108}$ were the greatest among all the fractions. Their averages over the measuring period are 10 and $9 \%$, respectively. $\mathrm{PM}_{0.4-1}$ had the highest mass concentration in the air; however, the 18 elements made less than $3.5 \%$ of the $\mathrm{PM}_{0.4-1}$ mass.

Non-metals $\mathrm{S}$ and $\mathrm{Cl}$ and crustal $\mathrm{Fe}, \mathrm{Ca}$, and $\mathrm{K}$ dominated in every of the 13 basic PM fractions. S and $\mathrm{Cl}$ accumulated in $\mathrm{PM}_{2.5}$. $\mathrm{Fe}, \mathrm{Ca}$, and, also crustal but occurring at concentrations lower than other crustal elements, $\mathrm{Sr}$ accumulated in coarse PM; for example, $\mathrm{PM}_{2.5-40}$-bound $\mathrm{Fe}$ was $77 \%$ of the total PM-bound Fe mass. On the other hand, the $\mathrm{K}$ contents of both the coarse particles and $\mathrm{PM}_{0.26-2.5}$ were high (Table 2).

The elements in fine PM come mainly from combustion (car engines, power plants, waste incinerators, household ovens, etc.). Coarse dust contains metals from natural sources (Chow et al. 1995). Iron is the most ubiquitous component of the Earth crust, and its greater ambient concentrations are associated with the occurrence of coarse rather than fine PM, like those of silicone or aluminum that are also of the natural origin. However, power station fly dust can contain $\mathrm{Al}, \mathrm{Ca}$, and $\mathrm{Fe}$ in its mineral components as well (Chow et al. 1995).

The mass distribution between fine and coarse PM confirm the natural origin of the crustal $\mathrm{Fe}, \mathrm{Ca}$, and $\mathrm{Sr}$ in September-December 2009 in Zabrze (soil re-suspension). However, K, which is also crustal, could have come from two sources: soil re-suspension and fuel combustion (Table 2; Chow 1995; Querol et al. 2007; Duvall et al. 2008; Rogula-Kozłowska et al. 2013a, c; 2014).

The measuring period averages of the ambient concentrations of the remaining elements depend on a fraction. The highest, those of the PM-related Mn, Zn, and $\mathrm{Pb}$, equal to 69,116 , and $38 \mathrm{ng} / \mathrm{m}^{3}$, respectively, are mainly due to $\mathrm{Mn}, \mathrm{Zn}$, and $\mathrm{Pb}$ contents in fine particles. The $\mathrm{Zn}$ concentrations in Zabrze are comparable with, or even lower, than those in other European urban locations. Instead, the $\mathrm{Mn}$ and $\mathrm{Pb}$ concentrations in Zabrze are among the European highest (Table 1). The PM-related $\mathrm{Cr}$, As, and $\mathrm{Cd}$ concentrations were similarly high; their measuring period averages are 5.2, 2.5, and $1.3 \mathrm{ng} / \mathrm{m}^{3}$, respectively. The ambient concentrations of these elements, although relatively high, did not exceed their ambient permissible values (WHO 2000). 
Table 2 The average concentrations of $13 \mathrm{PM}$ fractions $\left(\mu \mathrm{g} / \mathrm{m}^{3}\right)$ and of the fraction-bound elements $\left(\mathrm{ng} / \mathrm{m}^{3}\right)$

\begin{tabular}{|c|c|c|c|c|c|c|c|c|c|c|c|c|c|}
\hline & $0.03-0.06$ & $0.06-0.108$ & $0.108-0.17$ & $0.17-0.26$ & $0.26-0.4$ & $0.4-0.65$ & $0.65-1$ & $1-1.6$ & $1.6-2.5$ & $2.5-4.4$ & $4.4-6.8$ & $6.8-10$ & $>10$ \\
\hline PM & 0.15 & 0.38 & 0.76 & 2.21 & 3.72 & 8.38 & 8.37 & 5.34 & 2.35 & 1.98 & 1.41 & 1.30 & 1.67 \\
\hline $\mathrm{S}$ & 4.04 & 4.70 & 5.66 & 11.83 & 22.22 & 56.07 & 69.43 & 60.64 & 27.67 & 13.14 & 9.45 & 7.86 & 11.54 \\
\hline $\mathrm{Cl}$ & 4.95 & 4.62 & 10.00 & 24.24 & 48.08 & 135.09 & 140.85 & 103.9 & 41.24 & 36.51 & 34.76 & 23.78 & 25.62 \\
\hline $\mathrm{K}$ & 0.88 & 1.89 & 2.67 & 6.99 & 10.93 & 21.58 & 20.22 & 18.17 & 11.21 & 12.69 & 11.55 & 13.43 & 18.78 \\
\hline $\mathrm{Ca}$ & 0.09 & 0.04 & 0.08 & 0.09 & 0.11 & 0.32 & 0.83 & 4.87 & 12.72 & 26.56 & 30.91 & 40.66 & 55.79 \\
\hline $\mathrm{Cr}$ & 0.28 & 0.29 & 0.28 & 0.31 & 0.33 & 0.42 & 0.47 & 0.52 & 0.47 & 0.43 & 0.39 & 0.42 & 0.61 \\
\hline $\mathrm{Mn}$ & 5.57 & 5.27 & 5.35 & 5.01 & 4.92 & 4.61 & 5.23 & 5.97 & 5.4 & 5.13 & 4.96 & 5.19 & 6.12 \\
\hline $\mathrm{Fe}$ & $<\mathrm{DL}$ & $<\mathrm{DL}$ & $<\mathrm{DL}$ & $<\mathrm{DL}$ & 0.40 & 7.48 & 10.29 & 25.85 & 36.07 & 61.21 & 55.72 & 63.77 & 86.29 \\
\hline $\mathrm{Ni}$ & 0.02 & 0.01 & 0.02 & 0.02 & 0.02 & 0.05 & 0.04 & 0.02 & 0.01 & 0.01 & 0.02 & 0.02 & 0.03 \\
\hline $\mathrm{Cu}$ & 1.13 & 1.11 & 1.12 & 1.32 & 1.46 & 2.29 & 2.17 & 2.02 & 1.73 & 1.87 & 1.67 & 1.54 & 1.57 \\
\hline $\mathrm{Zn}$ & 0.84 & 1.21 & 1.83 & 4.98 & 8.9 & 25.61 & 25.52 & 19.96 & 7.65 & 4.92 & 3.83 & 4.42 & 6.16 \\
\hline $\mathrm{Ge}$ & 0.002 & $<\mathrm{DL}$ & 0.01 & 0.06 & 0.23 & 0.59 & 0.55 & 0.31 & 0.07 & 0.02 & $<\mathrm{DL}$ & $<\mathrm{DL}$ & 0.004 \\
\hline As & 0.09 & 0.07 & 0.11 & 0.09 & 0.23 & 0.63 & 0.46 & 0.33 & 0.11 & 0.16 & 0.05 & 0.17 & 0.04 \\
\hline $\mathrm{Br}$ & 0.06 & 0.15 & 0.23 & 0.78 & 1.43 & 4.12 & 3.6 & 2.19 & 0.56 & 0.22 & 0.06 & 0.04 & 0.06 \\
\hline $\mathrm{Sr}$ & 0.004 & 0.002 & 0.01 & $<\mathrm{DL}$ & $<\mathrm{DL}$ & $<\mathrm{DL}$ & $<\mathrm{DL}$ & 0.02 & 0.16 & 0.41 & 0.36 & 0.53 & 0.71 \\
\hline $\mathrm{Cd}$ & 0.01 & 0.01 & 0.02 & 0.08 & 0.09 & 0.36 & 0.27 & 0.2 & 0.05 & 0.06 & 0.05 & 0.02 & 0.04 \\
\hline $\mathrm{Sb}$ & 0.08 & 0.09 & 0.16 & 0.35 & 0.61 & 1.59 & 1.24 & 0.83 & 0.31 & 0.24 & 0.14 & 0.18 & 0.12 \\
\hline $\mathrm{Ba}$ & 0.03 & 0.03 & 0.01 & 0.07 & 0.03 & 0.11 & 0.15 & 0.52 & 0.82 & 1.30 & 1.21 & 1.43 & 2.02 \\
\hline $\mathrm{Pb}$ & 0.24 & 0.46 & 0.66 & 2.01 & 3.26 & 9.09 & 7.52 & 5.43 & 2.42 & 1.91 & 1.49 & 1.71 & 2.14 \\
\hline$\Sigma_{18}$ & 18.32 & 19.95 & 28.22 & 58.23 & 103.25 & 270.01 & 288.84 & 251.75 & 148.67 & 166.79 & 156.62 & 165.17 & 217.64 \\
\hline
\end{tabular}

$<D L$ concentrations lower than the detection limits, $\Sigma_{18}$ the ambient concentration of the PM-bound total of the 18 elements averaged over the measuring period

However, the health hazard from them could have been greater than this estimated from their concentrations because most of their mass was in very fine particles. In general, metals were occurred mostly in the fine PM fractions. The average mass shares of particular $\mathrm{PM}_{1}$ bound metals in their PM-bound totals range between
$45 \%(\mathrm{Cr})$ and $78 \%(\mathrm{Ge}) . \mathrm{PM}_{2.5}$ contained yet more metals - between $65 \%(\mathrm{Cr})$ and $99 \%(\mathrm{Ge})$ of the total metal content of PM.

The density functions of the mass size distributions of PM and seven selected elements are presented in Fig. 3 . Table 3 presents all the particle $D_{\mathrm{p}}$ intervals in
Fig. 2 The ranges of the ambient concentrations of the total of the 18 element by PM fractions

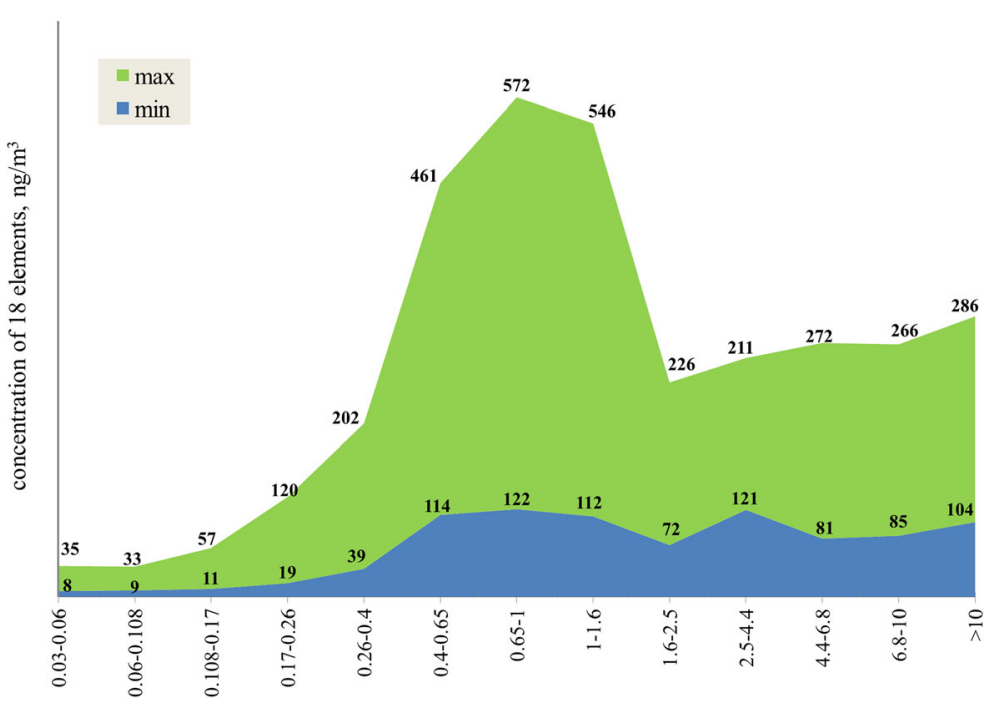




\section{PM}

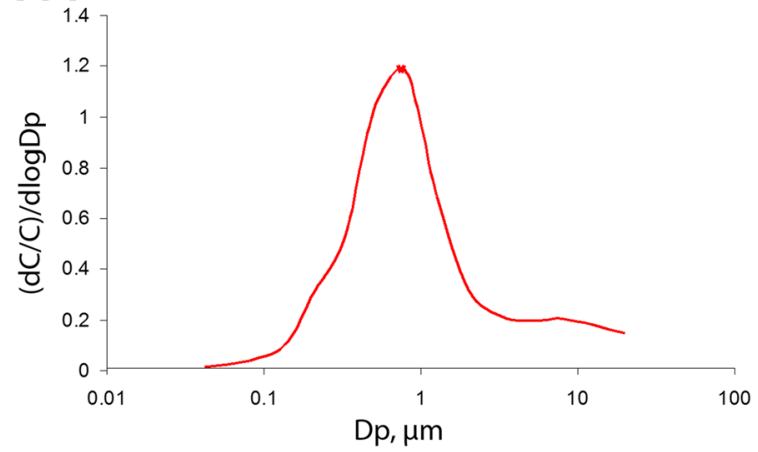

\section{Cl}

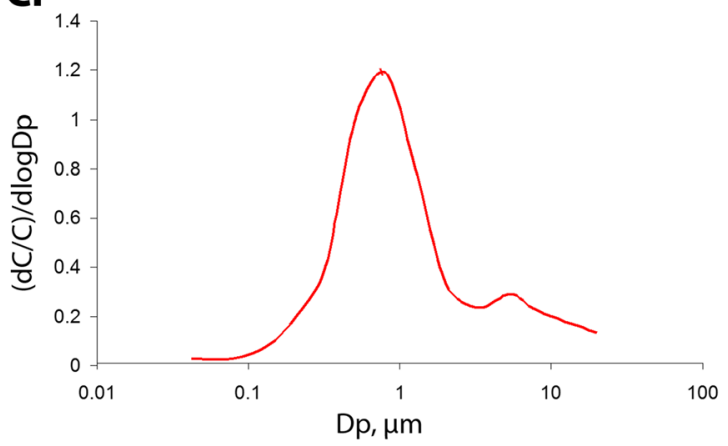

Fe

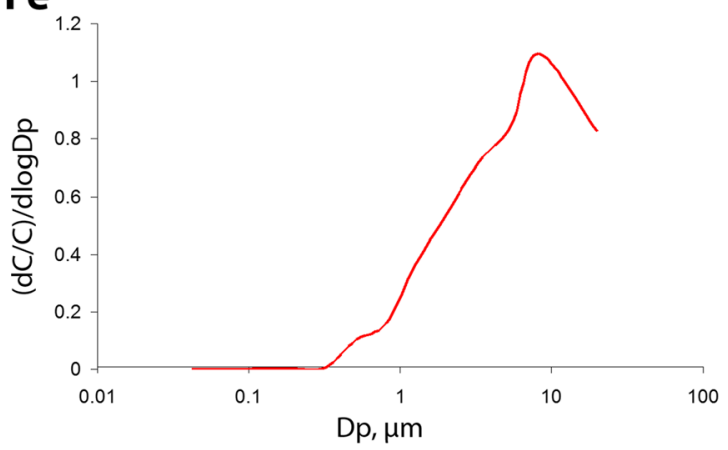

Sr

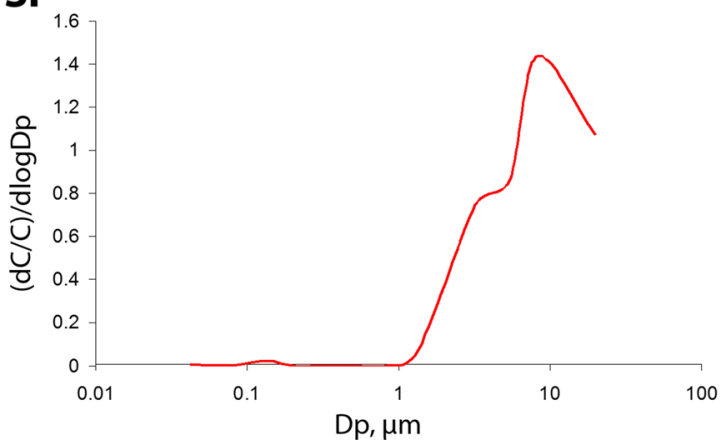

S

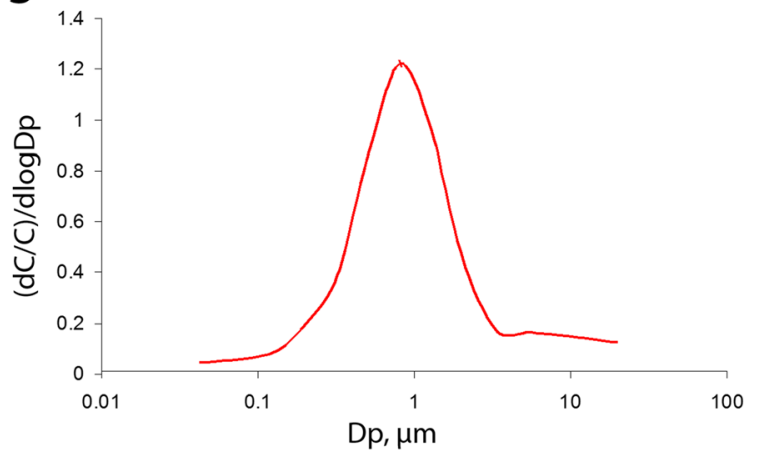

K

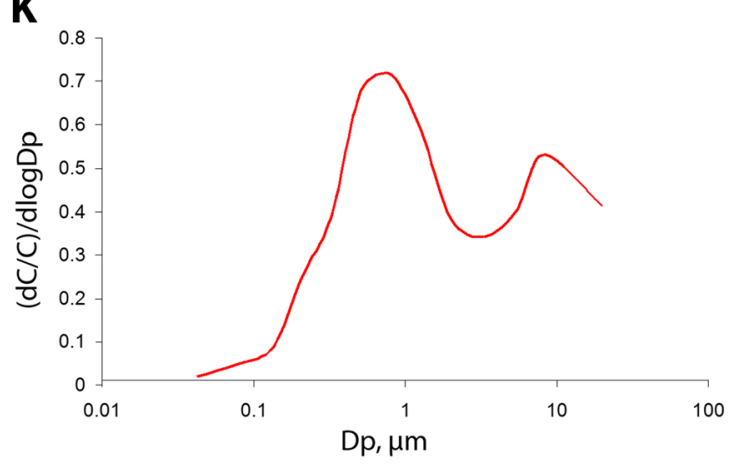

As

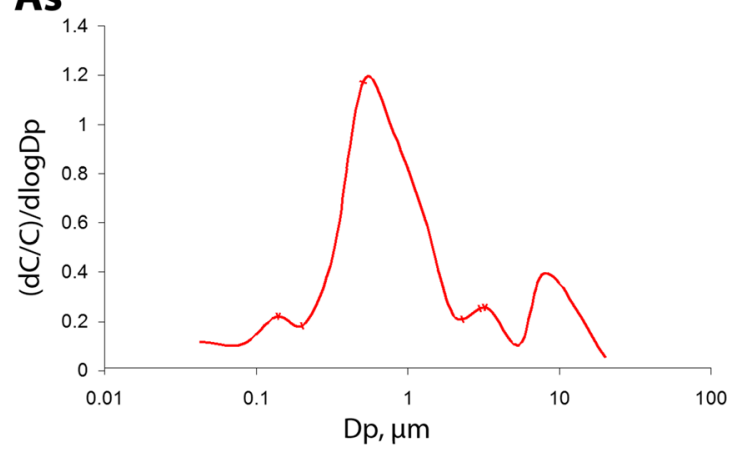

Cd

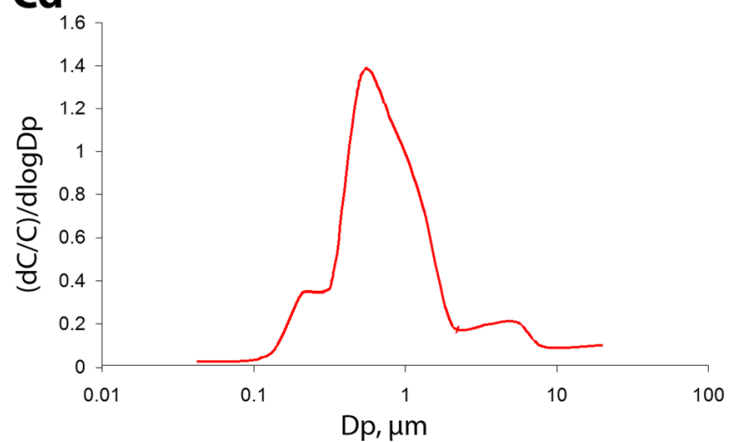

Fig. 3 The mass size distributions of the selected PM-bound elements ( $d C$ fraction-bound element concentration, $C$ average concentration of PM-bound element, $D p$ particle aerodynamic diameter) 
Table 3 The particle size intervals in which the maxima of the mass size distributions of PM and PM-related elements occur

\begin{tabular}{|c|c|c|c|c|}
\hline & Max 1 & Max 2 & Max 3 & $\operatorname{Max} 4$ \\
\hline PM & $0.65-1$ & $6.8-10$ & & \\
\hline $\mathrm{S}$ & $0.65-1$ & & & \\
\hline $\mathrm{Cl}$ & $0.65-1$ & $4.4-6.8$ & & \\
\hline $\mathrm{K}$ & $0.65-1$ & $6.8-10$ & & \\
\hline $\mathrm{Ca}$ & $6.8-10$ & & & \\
\hline $\mathrm{Cr}$ & $1-1.6$ & $6.8-10$ & & \\
\hline $\mathrm{Mn}$ & $0.108-0.17$ & $1-1.6$ & $6.8-10$ & \\
\hline $\mathrm{Fe}$ & $6.8-10$ & & & \\
\hline $\mathrm{Ni}$ & $0.4-0.65$ & $6.8-10$ & & \\
\hline $\mathrm{Cu}$ & $0.65-1$ & $6.8-10$ & & \\
\hline $\mathrm{Zn}$ & $0.65-1$ & $6.8-10$ & & \\
\hline $\mathrm{Ge}$ & $0.65-1$ & & & \\
\hline As & $0.108-0.17$ & $0.4-0.65$ & $2.5-4.4$ & $6.8-10$ \\
\hline $\mathrm{Br}$ & $0.4-0.65$ & & & \\
\hline $\mathrm{Sr}$ & $0.108-0.17$ & $6.8-10$ & & \\
\hline $\mathrm{Cd}$ & $0.4-0.65$ & $4.4-6.8$ & & \\
\hline $\mathrm{Sb}$ & $0.4-0.65$ & $6.8-10$ & & \\
\hline $\mathrm{Ba}$ & $0.06-0.108$ & $0.17-0.26$ & $6.8-10$ & \\
\hline $\mathrm{Pb}$ & $0.4-0.65$ & $6.8-10$ & & \\
\hline
\end{tabular}

which the maxima of these functions occur, for all the discussed elements and PM.

The density function of PM mass distribution with respect to particle size at a given receptor has usually several maxima (modes; 2, 3, less often 4; Hinds 1998). Each maximum characterizes a population of particles (also called mode). Each population has its separate distribution (lognormal; Whitby 1978; Whitby and McMurry 1997). The populations partly overlap, and the set of those distributions is characteristic of the place in which it occurs.

The mass size distribution of PM in Zabrze for the heating period of 2009 is bimodal (Fig. 3). The first maximum of its density function occurs between 0.65 and $1 \mu \mathrm{m}$ (accumulation mode; Fig. 3, Table 3), the second between 6.8 and $10 \mu \mathrm{m}$ (coarse mode). It corroborates the results of earlier studies (Klejnowski et al. 2012) that suggest that two particle mass populations dominate the PM in Zabrze. They are fine primary $\mathrm{PM}$ originating from combustion, and coarse PM from re-suspended road and soil dust, erosion of various materials, etc. (Chow 1995; Hinds 1998; Karanasiou et al. 2011; Kumar et al. 2013; Pant and Harrison 2013).
The numbers of the maxima of the density functions of the considered elements and the intervals of these maxima occurrence differ.

Eight elements ( $\mathrm{Cl}, \mathrm{K}, \mathrm{Ni}, \mathrm{Cu}, \mathrm{Zn}, \mathrm{Cd}, \mathrm{Sb}, \mathrm{Pb})$, like $\mathrm{PM}$, have bimodal distributions, with one maximum within the interval of great $D_{\mathrm{p}}$ (most often between 6.8 and $10 \mu \mathrm{m}$; for $\mathrm{Cl}$ and $\mathrm{Cd}$ between 4.4 and $6.8 \mu \mathrm{m}$ ) and the second one within the small $D_{\mathrm{p}}$ (between 0.4 and $1 \mu \mathrm{m})$. Therefore, these PM-bound elements could have come from anthropogenic sources (fossil fuels and biomass combustion, accumulation mode), natural sources (mineral dust), and mechanical processes (brake system wear and road dust re-suspension; coarse mode) (Garg et al. 2000; Sternbeck et al. 2002; Adachi and Tainosho 2004; Slezakowa et al. 2007; Gaudry et al. 2008; Pant and Harrison 2013), having multiple origins. In general, $\mathrm{Zn}, \mathrm{Ni}, \mathrm{Cu}, \mathrm{Sb}, \mathrm{Cd}$, and $\mathrm{Pb}$ occur in car exhaust (Chow 1995; Geller et al. 2006; Maricq 2007; Dias da Silva et al. 2008; Pant and Harrison 2013); some researchers consider $\mathrm{Zn}$ an indicator of the road dust re-suspension (tire wear) in urban areas (Amato et al. 2009, 2011).

Each, the bimodal $\mathrm{Cr}$ and the three-modal Mn mass size distributions, have two modes in $D_{\mathrm{p}}>1 \mu \mathrm{m}$. Probably, these elements came from fragments of brake linings and tires in re-suspended road dust (Kupiainen et al. 2005; Wahlin et al. 2006; Amato et al. 2009, 2011; Harrison et al. 2012; Pant and Harrison 2013). Mn, like As and $\mathrm{Ba}$, might have come from the nucleation processes - the maxima of the density functions of their distributions occur within the interval of the smallest $D_{\mathrm{p}}$ (Table 3; Fig. 3). The regularly shaped particles of metal oxides, being the condensation centers for the finest PM, indicate the influence of high-temperature processes (e.g., steel and iron working; Moreno et al. 2004; Mogo et al. 2005) or of road traffic (Geller et al. 2006; Maricq 2007) on the formation of the PM particles.

The mass size distributions of $\mathrm{S}, \mathrm{Ge}$, and $\mathrm{Br}$ are unimodal; the maxima occur between 0.65 and $1.0 \mu \mathrm{m}$ for $\mathrm{S}$ and $\mathrm{Ge}$, and between 0.4 and $0.65 \mu \mathrm{m}$ for $\mathrm{Br}$. It means that the airborne $\mathrm{S}, \mathrm{Ge}$, and $\mathrm{Br}$ in Zabrze were anthropogenic.

The behavior of the ambient crustal element concentrations confirms the natural origin of greater parts of airborne $\mathrm{Fe}, \mathrm{Ca}$, and $\mathrm{Sr}$ (soil re-suspension). However, while the mass size distributions of $\mathrm{Fe}$ and $\mathrm{Ca}$, typical crustal elements coming solely from soil matter, are unimodal that of $\mathrm{Sr}$ is bimodal (Fig. 3; Table 3). Each of the three density functions has one maximum 
Table 4 The enrichment factors (EF) for the elements in 13 PM fractions

\begin{tabular}{lrrrrrrrrrrrrrr}
\hline & ${ }^{I} U C C$, & $0.03-$ & $0.06-$ & $0.108-$ & $0.17-$ & $0.26-$ & $0.4-$ & $0.65-$ & $1-$ & $1.6-$ & $2.5-$ & $4.4-$ & $6.8-$ & $>10$ \\
& $p p m$ & 0.06 & 0.108 & 0.17 & 0.26 & 0.4 & 0.65 & 1 & 1.6 & 2.5 & 4.4 & 6.8 & 10 & \\
\hline $\mathrm{S}$ & 953 & 1387 & 3631 & 2186 & 4062 & 6242 & 5415 & 2585 & 385 & 67 & 15 & 9 & 6 & 6 \\
$\mathrm{Cl}$ & 640 & 2531 & 5315 & 5752 & 12394 & 20113 & 19426 & 7809 & 982 & 149 & 63 & 52 & 27 & 21 \\
$\mathrm{~K}$ & 28650 & 10 & 49 & 34 & 80 & 102 & 69 & 25 & 4 & 1 & $<1$ & $<1$ & $<1$ & $<1$ \\
$\mathrm{Ca}$ & 29450 & 1 & 1 & 1 & 1 & 1 & 1 & 1 & 1 & 1 & 1 & 1 & 1 & 1 \\
$\mathrm{Cr}$ & 35 & 2618 & 6100 & 2945 & 2898 & 2524 & 1104 & 476 & 90 & 31 & 14 & 11 & 9 & 9 \\
$\mathrm{Mn}$ & 527 & 3458 & 7363 & 3737 & 3111 & 2499 & 805 & 352 & 69 & 24 & 11 & 9 & 7 & 6 \\
$\mathrm{Fe}$ & 30890 & - & - & - & - & 3 & 22 & 12 & 5 & 3 & 2 & 2 & 1 & 1 \\
$\mathrm{Ni}$ & 18.6 & 352 & 396 & 396 & 352 & 288 & 247 & 76 & 7 & 1 & 1 & 1 & 1 & 1 \\
$\mathrm{Cu}$ & 14.3 & 25857 & 57149 & 28832 & 30205 & 27334 & 14738 & 5384 & 854 & 280 & 145 & 111 & 78 & 58 \\
$\mathrm{Zn}$ & 52 & 5286 & 17132 & 12955 & 31338 & 45823 & 45325 & 17413 & 2321 & 341 & 105 & 70 & 62 & 63 \\
$\mathrm{Ge}$ & - & - & - & - & - & - & - & - & - & - & - & - & - & - \\
$\mathrm{As}$ & 2 & 14725 & 25769 & 20247 & 14725 & 30789 & 28990 & 8161 & 998 & 127 & 89 & 24 & 62 & 11 \\
$\mathrm{Br}$ & 1.6 & 12271 & 69023 & 52918 & 159521 & 239281 & 236980 & 79834 & 8277 & 810 & 152 & 36 & 18 & 20 \\
$\mathrm{Sr}$ & 316 & 4 & 5 & 12 & - & - & - & - & $<1$ & 1 & 1 & 1 & 1 & 1 \\
$\mathrm{Cd}$ & 0.102 & 32081 & 72181 & 72181 & 256645 & 236230 & 324816 & 93923 & 11857 & 1135 & 652 & 467 & 142 & 207 \\
$\mathrm{Sb}$ & 0.31 & 84444 & 213750 & 190000 & 369444 & 526818 & 472031 & 141928 & 16191 & 2315 & 858 & 430 & 421 & 204 \\
$\mathrm{Ba}$ & 668 & 15 & 33 & 6 & 34 & 12 & 15 & 8 & 5 & 3 & 2 & 2 & 2 & 2 \\
$\mathrm{~Pb}$ & 17 & 4620 & 19922 & 14292 & 38689 & 51341 & 49210 & 15696 & 1932 & 330 & 125 & 84 & 73 & 66 \\
\hline
\end{tabular}

${ }^{\mathrm{T}}$ Element content (ppm) in the upper continental crust; data taken from (Wedepohl 1995); the symbols in red are the symbols of elements whose EFs for some fractions are high, indicating the anthropogenic effect on these element contents in PM

between 6.8 and $10 \mu \mathrm{m}$; the $\mathrm{Sr}$ distribution has also the maximum between 0.108 and $0.17 \mu \mathrm{m}$. This bimodality of the $\mathrm{Sr}$ distribution indicates the existence and effects of an anthropogenic $\mathrm{Sr}$ source(s) affecting the measuring point in Zabrze.

The possible anthropogenic effect on the ambient concentrations of the PM-related elements can be assessed by computing enrichment factors (EF, Table 4). The enrichment factor $\mathrm{EF}_{\mathrm{x}}$ for the element $x$ is defined as:

$$
\mathrm{EF}_{x}=\frac{\left(C_{x} / C_{\text {ref }}\right)_{\mathrm{PM}}}{\left(C_{x} / C_{\text {ref }}\right)_{\text {crust }}}
$$

where $C_{x}$ and $C_{\text {ref }}$ are the concentrations of the element $x$ and the reference element, and $\left(C_{x} / C_{\mathrm{ref}}\right)_{\mathrm{PM}}$ and $\left(C_{x} /\right.$ $\left.C_{\text {ref }}\right)_{\text {crust }}$ are the proportions of these concentrations in $\mathrm{PM}$ and in the Earth crust, respectively. Ca was assumed as the reference element, i.e., $\mathrm{EF}_{\mathrm{Ca}}=1$. The chemical composition of the upper continental crust was taken from (Wedepohl 1995). The closer $\mathrm{EF}_{\mathrm{x}}$ is to 1, the weaker are the anthropogenic effects on the element $\mathrm{x}$ ambient concentrations.
The EF analysis confirmed the origin of the PMbound elements in Zabrze. The $\mathrm{PM}_{1}$-bound elements (except $\mathrm{Fe}, \mathrm{Sr}$, and $\mathrm{Ba}$ ) have very high $\mathrm{EFs}$, the coarse PM-bound ones - much lower; thus, it is certain that the anthropogenic emissions account for their contents in fine PM. The measurement period and the sampling point location suggest that combustion of fuels in household ovens and car engines were their sources. It is also true of $\mathrm{Fe}$, which, despite its unimodal distribution (maximum within the interval of great $D_{\mathrm{p}}$ ) and low EFs for the fractions of particles with $D_{\mathrm{p}}>1 \mu \mathrm{m}$, has higher EFs for the sub-fractions of $\mathrm{PM}_{0.4-1}$.

$\mathrm{S}, \mathrm{Cl}, \mathrm{Cr}, \mathrm{Mn}, \mathrm{Cu}, \mathrm{As}, \mathrm{Br}$, and $\mathrm{Pb}$ in coarse PM could have come from re-suspended polluted soil or road dust. Low, not greater than 1, EFs for coarse PM-bound K, $\mathrm{Ni}, \mathrm{Sr}$, and Ba prove mineral matter (soil) to have been the main source of these elements in coarse PM.

Principal component analysis ${ }^{1}$ (PCA; Larose 2012) was applied separately to each of the 13 PM fractionrelated sets of the 18 element concentrations, taking the 18 PM-bound element concentrations as the predictors.

\footnotetext{
${ }^{1}$ Calculated with Statistica (Stat Soft) and customized Eco Data Miner (Czechowski 2009).
} 
Table 5 The loadings of 13 fraction-related PC1

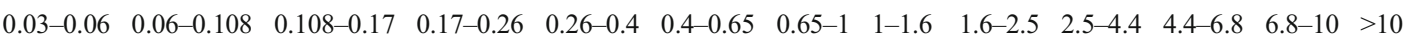

\begin{tabular}{|c|c|c|c|c|c|c|c|c|c|c|c|c|c|}
\hline $\mathrm{S}$ & 0.93 & -0.94 & 0.93 & -0.97 & -0.85 & -0.67 & -0.70 & -0.89 & -0.88 & -0.51 & -0.76 & -0.95 & -0.90 \\
\hline $\mathrm{Cl}$ & 0.95 & -0.74 & 0.80 & -0.75 & -0.85 & -0.66 & -0.66 & -0.82 & 0.12 & 0.43 & 0.04 & -0.29 & 0.41 \\
\hline $\mathrm{K}$ & 0.77 & -0.97 & 0.96 & -0.90 & -0.94 & -0.94 & -0.91 & -0.92 & -0.96 & -0.92 & -0.94 & -0.89 & -0.97 \\
\hline $\mathrm{Ca}$ & 0.58 & -0.54 & -0.47 & -0.33 & -0.66 & -0.74 & -0.75 & -0.67 & -0.79 & -0.82 & -0.96 & -0.94 & -0.99 \\
\hline $\mathrm{Cr}$ & 0.84 & -0.46 & 0.35 & -0.52 & -0.76 & -0.76 & -0.94 & -0.80 & -0.10 & -0.35 & -0.82 & -0.82 & -0.89 \\
\hline Mn & 0.62 & 0.04 & -0.30 & -0.14 & 0.05 & -0.20 & -0.62 & -0.64 & -0.54 & -0.41 & -0.30 & -0.28 & -0.45 \\
\hline $\mathrm{Fe}$ & - & - & - & - & 0.52 & -0.45 & -0.87 & -0.89 & -0.94 & -0.94 & -0.98 & -0.96 & -0.96 \\
\hline $\mathrm{Ni}$ & 0.82 & -0.67 & 0.38 & -0.68 & -0.77 & -0.85 & -0.96 & -0.86 & 0.14 & 0.16 & -0.62 & -0.66 & -0.70 \\
\hline $\mathrm{Cu}$ & 0.86 & -0.78 & 0.64 & -0.91 & -0.94 & -0.95 & -0.96 & -0.93 & -0.91 & -0.92 & -0.84 & -0.90 & -0.62 \\
\hline $\mathrm{Zn}$ & 0.93 & -0.98 & 0.96 & -0.95 & -0.96 & -0.97 & -0.95 & -0.96 & -0.98 & -0.76 & -0.94 & -0.97 & -0.96 \\
\hline $\mathrm{Ge}$ & 0.16 & - & 0.51 & -0.37 & -0.87 & -0.72 & -0.63 & -0.76 & -0.75 & -0.36 & - & - & 0.12 \\
\hline As & 0.67 & 0.69 & 0.46 & -0.30 & -0.51 & 0.07 & 0.46 & 0.14 & -0.22 & 0.04 & -0.52 & 0.36 & -0.14 \\
\hline $\mathrm{Br}$ & 0.86 & -1.00 & 0.98 & -0.96 & -0.99 & -0.96 & -0.93 & -0.97 & -0.81 & -0.49 & -0.54 & -0.87 & -0.86 \\
\hline $\mathrm{Sr}$ & -0.13 & -0.24 & 0.45 & - & - & - & - & 0.28 & -0.24 & -0.67 & -0.89 & -0.95 & -0.93 \\
\hline $\mathrm{Cd}$ & -0.46 & -0.46 & -0.36 & -0.80 & -0.29 & -0.93 & -0.82 & -0.24 & 0.66 & 0.85 & -0.44 & -0.21 & -0.41 \\
\hline $\mathrm{Sb}$ & 0.25 & -0.46 & 0.80 & -0.68 & -0.87 & -0.95 & -0.95 & -0.98 & -0.89 & -0.65 & -0.79 & -0.91 & -0.11 \\
\hline $\mathrm{Ba}$ & 0.26 & -0.10 & -0.35 & -0.61 & 0.09 & -0.58 & -0.87 & -0.85 & -0.97 & -0.97 & -0.96 & -0.96 & -0.82 \\
\hline $\mathrm{Pb}$ & 0.80 & -0.94 & 0.97 & -0.99 & -0.97 & -0.95 & -0.96 & -0.96 & -0.63 & 0.27 & -0.80 & -0.85 & -0.78 \\
\hline Eigenvalue & 8.24 & 7.75 & 7.81 & 8.51 & 9.80 & 10.15 & 11.79 & 11.38 & 9.22 & 7.56 & 9.80 & 10.81 & 9.69 \\
\hline Variance, \% & 48 & 48 & 46 & 53 & 58 & 60 & 69 & 63 & 51 & 42 & 58 & 64 & 54 \\
\hline
\end{tabular}

Loadings whose absolute values are greater than 0.7 are indicated in italics

Only from 3 to 5 first principal components had their eigenvalues greater than 1 (Guttmann-Kaiser criterion, Kleinbaum et al. 1998; Larose 2012). Together, these PCs account for $90.1 \%\left(\mathrm{PM}_{0.4-0.65}\right)$ to $99.7 \%\left(\mathrm{PM}_{4.4}\right.$ 6.8) of the fraction data set variance, the $\mathrm{PC} 1 \mathrm{~s}$ contribute from 42 to $69 \%$ to it, and only one PC2, that for $\mathrm{PM}_{0.06-}$ 0.108 , contributes more than $30 \%$. The remaining PC2s contribute no more than 17 to $23 \%$, depending on fraction, and no PC3, PC4, or PC5 contribute more than $15 \%$. The loadings for all the $13 \mathrm{PC} 1 \mathrm{~s}$ are presented in Table 5.

For each of the basic 13 PM fraction, its PC1 represents its most effective source (Hopke et al. 1976; Thurston and Spengler 1985; Sówka et al. 2012). The fractions were grouped by applying cluster analysis (CA) to the 13 first principal components received from PCA (Fig. 4; Ward's method, minimum variance criterion; Larose 2012; Kleinbaum et al. 1998). Such an application of CA allowed for grouping the basic PM fractions in regard to their most probable origin in four clearly distinguished clusters (Fig. 4; Hopke et al. 1976): $\left(\mathrm{PM}_{0.03-0.06}\right.$, $\left.\mathrm{PM}_{0.108-0.17}\right),\left(\mathrm{PM}_{1.6-2.5}, \mathrm{PM}_{2.5-4.4}\right),\left(\mathrm{PM}_{0.06-0.108}\right.$, $\mathrm{PM}_{0.17-0.26}, \mathrm{PM}_{0.26-0.4}, \mathrm{PM}_{0.4-0.65}, \mathrm{PM}_{0.65-1}, \mathrm{PM}_{1-1.6}$ ), and $\left(\mathrm{PM}_{4.4-6.8}, \mathrm{PM}_{6.8-10}, \mathrm{PM}_{>10}\right)$. These clusters match roughly the four particle populations revealed by the mass size distributions of PM and PM-bound elements, i.e., two sub-populations of coarse particles, accumulation population, and nucleation population, related to different sources.

For the five sub-fractions of $\mathrm{PM}_{0.4}$, the concentrations of $\mathrm{S}, \mathrm{Cl}, \mathrm{K}, \mathrm{Cu}, \mathrm{Zn}, \mathrm{Br}$, and $\mathrm{Pb}$ are highly corre-

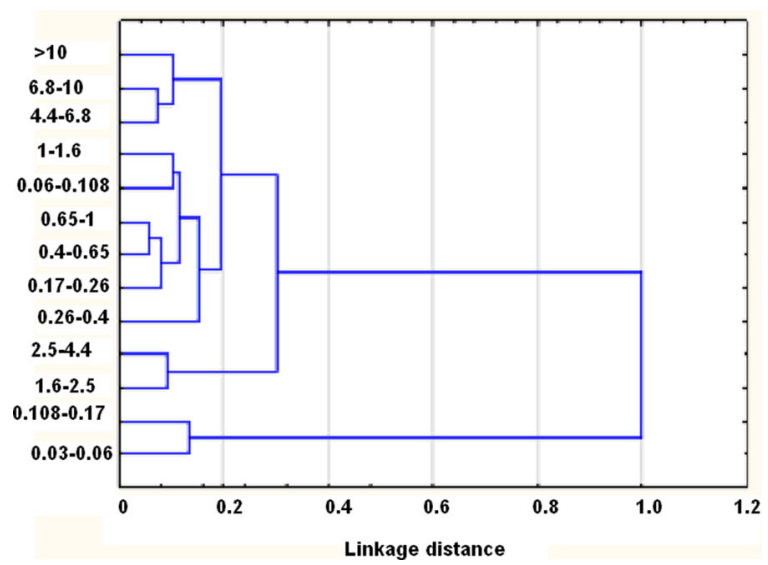

Fig. 4 Dendrogram of cluster analysis (Ward's method): the basic PM fractions grouped by similarity of their probable origin 
lated with PC1s, negatively for $\mathrm{PM}_{0.17-0.26}, \mathrm{PM}_{0.26-0.4 \text {, }}$ and $\mathrm{PM}_{0.06-0.108}$, positively for $\mathrm{PM}_{0.108-0.17}$ and $\mathrm{PM}_{0.03-}$ 0.06 (except for $\mathrm{Cu}$ in $\mathrm{PM}_{0.108-0.17}$ ). The concentrations of $\mathrm{PM}_{0.26-0.4^{-}}$and $\mathrm{PM}_{0.03-0.06}$-bound $\mathrm{Cr}$ and $\mathrm{Ni}, \mathrm{PM}_{0.26}$ 0.4 -bound $\mathrm{Ge}$, and $\mathrm{PM}_{0.17-0.26}$-bound $\mathrm{Cd}$ are also highly correlated with PC1s. The high correlation between S and $\mathrm{PC} 1$ in such fine particles may be due to the secondary aerosol content (Seinfeld and Pandis 1998), but the modality of the PM-bound S concentration distribution does not confirm this. The remaining $\mathrm{PM}_{0.4}$-bound elements correlated with $\mathrm{PC} 1 \mathrm{~s}$ originated mainly from car exhaust (Chow 1995; Birmili et al. 2006; Geller et al. 2006; Maricq 2007; Daher et al. 2014). Probably, they occurred as airborne metal oxides (condensation centers) or metal salts (presence of $\mathrm{S}, \mathrm{Cl}, \mathrm{Br}$ ).

Two sub-fractions of $\mathrm{PM}_{0.4}, \mathrm{PM}_{0.03-0.06}$, and $\mathrm{PM}_{0.108-}$ 0.17 make one cluster. Their probable common main source might have been car exhaust. However, the three remaining $\mathrm{PM}_{0.4}$ sub-fractions are in one cluster with $\mathrm{PM}_{0.4-0.65}, \mathrm{PM}_{0.65-1}, \mathrm{PM}_{1-1.6}$, summing to $\mathrm{PM}_{0.4-1.6}$ (Fig. 4). The concentrations of the majority of the examined elements are highly correlated with PC1s for these three sub-fractions of $\mathrm{PM}_{0.4-1.6}$, like those for the subfractions of $\mathrm{PM}_{0.4}$ that are associated with combustion processes. CA suggests these processes to be the same as for $\mathrm{PM}_{0.06-0.108}, \mathrm{PM}_{0.17-0.26}$, and $\mathrm{PM}_{0.26-0.4}$, but different from the source of $\mathrm{PM}_{0.03-0.06}$ and $\mathrm{PM}_{0.108-0.17}$.

However, the PC1s for the sub-fractions of $\mathrm{PM}_{0.4-1}$, besides being negatively correlated with the concentrations of $\mathrm{K}, \mathrm{Cr}, \mathrm{Ni}, \mathrm{Cu}, \mathrm{Zn}, \mathrm{Br}, \mathrm{Cd}, \mathrm{Sb}$, and $\mathrm{Pb}$, are also correlated with the concentrations of $\mathrm{Ca}$. Because $\mathrm{Ca}$ has been shown to be of the natural origin (soil) in each fraction, the PM natural sources are supposed to have affected $\mathrm{PM}_{0.4-1}$.

Undoubtedly, most elements in the fine PM came from combustion. On the other hand, mineral matter and, probably, road dust were the sources of the majority of the elements in the coarse PM. For the sub-fractions of $\mathrm{PM}_{1.6-40}$, the PC1s (42 to $64 \%$ of variance) are correlated with the concentrations of $\mathrm{Ca}, \mathrm{Fe}, \mathrm{Sr}$, and $\mathrm{Ba}$. Moreover, these $\mathrm{PC} 1 \mathrm{~s}$ are also correlated with the concentrations of $\mathrm{S}, \mathrm{K}, \mathrm{Cr}, \mathrm{Cu}, \mathrm{Zn}, \mathrm{Br}, \mathrm{Sb}$, and $\mathrm{Pb}$. Probably, the three coarsest PM fractions $\left(D_{\mathrm{p}} \geq 4.4 \mu \mathrm{m}\right)$, whose PC1s are correlated with $\mathrm{Br}$ and $\mathrm{S}$, and with the metals $\mathrm{Cr}$ and $\mathrm{Sb}$, were in part composed of re-suspended road dust (Amato et al. 2009; Karanasiou et al. 2011; Harrison et al. 2012). These fractions are in one cluster; they had a common main source (Fig. 4).

The two sub-fractions of $\mathrm{PM}_{1.6-4.4}$ make also one cluster. They differ from the coarser fractions in the lack of the correlations between their $\mathrm{PC} 1 \mathrm{~s}$ and $\mathrm{Cr}, \mathrm{Mn}, \mathrm{Sr}$, and $\mathrm{Pb}$, and for $\mathrm{PM}_{2.5-4.4}$ also between $\mathrm{PC} 1$ and $\mathrm{S}$ and $\mathrm{Cl}$. These two fractions may have come from re-suspended soil polluted with metals.

However, the variety of PM sources in Zabrze and, in general, unknown elemental composition of the PM they release do not allow to exclude the effects of fuel combustion on the elemental composition of coarse PM (e.g., metal compounds adsorbed on soot particles); similarly, the effects of mechanical processes, such as wear of brake linings, tires, and road surface may have added some amounts of metals to ultrafine and fine PM (Sanderson et al. 2014).

\section{Summary}

In the heating season of 2009, in an urban locality in Zabrze (southern Poland), PM-bound $\mathrm{S}, \mathrm{Cl}, \mathrm{Fe}, \mathrm{Ca}$, and $\mathrm{K}$ had the highest ambient concentrations among all the examined PM-bound elements. The concentrations of $\mathrm{Mn}, \mathrm{Zn}$, and $\mathrm{Pb}$ were the second highest. Most of the elements (except typically crustal) concentrated their masses in particles with $D_{\mathrm{p}} \leq 1\left(\mathrm{PM}_{1}\right)$. Majority of toxic metals had their greater PM mass shares in the finest PM; their toxicity combining with the physicochemical properties of the finest PM caused health hazard. The concentrations of the most toxic $\mathrm{Pb}, \mathrm{Cr}$, As, and $\mathrm{Cd}$ did not exceed the permissible values (WHO 2000), but, compared to the concentrations in other European cities, their ambient concentrations in Zabrze were high.

Determination of the particle size resolved elemental composition of PM, supporting the PM source apportionment, allowed to identify the hypothetic sources of $\mathrm{PM}$ in the particular particle size ranges. The identification was based on the analyses of the modality of mass size distributions of the PM-bound elements, principal component analysis (PCA), and cluster analysis (CA).

The PM mass size distribution in Zabrze for September-December 2009 is bimodal, it has the coarse and the accumulation modes. The mass size distributions of the PM-bound elements have from two to four modes, one and/or two coarse modes, and/or an accumulation mode, and/or a nucleation mode, depending on an element. The two coarse populations were probably the soil (mineral) particles and the re-suspended particles of the polluted soil or road dust (from the brake linings, tires, road surface, cars, etc.). The typical crustal elements $(\mathrm{Ca}, \mathrm{Fe}, \mathrm{Sr}$, and $\mathrm{Ba})$ characterized the particles of 
one coarse population, the same crustal elements and $\mathrm{S}$, $\mathrm{K}, \mathrm{Cr}, \mathrm{Cu}, \mathrm{Zn}, \mathrm{Br}, \mathrm{Sb}$, and $\mathrm{Pb}$ were in the particles of the second. These two populations contained the particles with $D_{\mathrm{p}}>1.6 \mu \mathrm{m}$. The particles with $D_{\mathrm{p}}$ between 0.108 and $1.6 \mu \mathrm{m}$, in accumulation mode, contained the elements $\mathrm{S}, \mathrm{Cl}, \mathrm{K}, \mathrm{Cu}, \mathrm{Zn}, \mathrm{Ge}, \mathrm{Br}, \mathrm{Cd}, \mathrm{Sb}$, and $\mathrm{Pb}$ that are characteristic of fuel combustion in stationary furnaces (coal, biomass, and waste burned in obsolete household ovens; hard and brown coal-fired heating boilers in residential areas). The particles with $D_{\mathrm{p}} \leq 0.108 \mu \mathrm{m}$ in the nucleation mode could have also come from road traffic (car exhaust particles).

The source apportionment accomplished by using principal component (PCA) and cluster (CA) analyses was in agreement with that done by analyzing the modality of mass size distributions of the PM-bound elements.

There are four clear-cut groups of the PM fractions identified by applying $\mathrm{CA}$ to the $13 \mathrm{PC} 1 \mathrm{~s}$ received from PCA: $\left(\mathrm{PM}_{1.6-2.5}, \mathrm{PM}_{2.5-4.4}\right),\left(\mathrm{PM}_{0.03-0.06}, \mathrm{PM}_{0.108-0.17}\right)$, $\left(\mathrm{PM}_{0.06-0.108}, \mathrm{PM}_{0.17-0.26}, \mathrm{PM}_{0.26-0.4}, \mathrm{PM}_{0.4-0.65}\right.$, $\left.\mathrm{PM}_{0.65-1}, \mathrm{PM}_{1-1.6}\right)$, and $\left(\mathrm{PM}_{4.4-6.8}, \mathrm{PM}_{6.8-10}, \mathrm{PM}_{>10}\right)$. These clusters match roughly the four particle populations revealed earlier by analyzing the mass size distributions of PM and PM-bound elements (two coarse particle populations, accumulation and nucleation populations related to different sources). Probably, road traffic (exhaust gases) was the basic source of $\mathrm{PM}_{0.03-0.06}$ and $\mathrm{PM}_{0.108-0.17}$ in the area; $\mathrm{PM}_{0.06-0.108}, \mathrm{PM}_{0.17-0.26}$, $\mathrm{PM}_{0.26-0.4}, \mathrm{PM}_{0.4-0.65}, \mathrm{PM}_{0.65-1}$, and $\mathrm{PM}_{1-1.6}$ came also from combustion but their main source was different from that of $\mathrm{PM}_{0.03-0.06}$ and $\mathrm{PM}_{0.108-0.17}$. Some of these fractions may have come partly from re-suspension of soil particles, like $\mathrm{PM}_{2.5-4.4}$, or of road dust, like $\mathrm{PM}_{>4.4}$.

\section{Ethical statement}

Funding The work was carried out within the projects No N523 564038 (ID 72074) and No 2012/07/D/ST10/02895 (ID 202319) financed by the National Science Centre, Poland (NCN).

Conflict of interest The authors declare that they have no conflict of interest.

Open Access This article is distributed under the terms of the Creative Commons Attribution 4.0 International License (http:// creativecommons.org/licenses/by/4.0/), which permits unrestricted use, distribution, and reproduction in any medium, provided you give appropriate credit to the original author(s) and the source, provide a link to the Creative Commons license, and indicate if changes were made.

\section{References}

Adachi, K., \& Tainosho, Y. (2004). Characterization of heavy metal particles embedded in tire dust. Environment International, 30, 1009-1017.

Aldabe, J., Elustondo, D., Santamaría, C., Lasheras, E., Pandolfi, M., Alastuey, A., Querol, X., \& Santamaría, J. M. (2011). Chemical characterization and source apportionment of PM2.5 and PM10 at rural, urban and traffic sites in Navarra (North of Spain). Atmospheric Research, 102, 191-205.

Almeida, S. M., Farinha, M. M., Ventura, M. G., Pio, C. A., Freitas, M. C., \& Reis, M. A. (2007). Measuring air particulate matter in large urban areas for health effect assessment. Water, Air, and Soil Pollution, 179, 43-55.

Amato, F., Pandolfi, M., Escrig, A., Querol, X., Alastuey, A., Pey, J., Pérez, N., \& Hopke, P. K. (2009). Quantifying road dust resuspensión in urban environment by Multilinear Engine: a comparison with PMF2. Atmospheric Environment, 43, 2770-2780.

Amato, F., Pandolfi, M., Moreno, T., Furger, M., Pey, J., Alastuey, A., Bukowiecki, N., Prévôt, A. S. H., Baltensperger, U., \& Querol, X. (2011). Sources and variability of inhalable road dust particles in three European cities. Atmospheric Environment, 45(37), 6777-6787.

Arhami, M., Sillanpää, M., Hu, S., Olson, M. R., Schauer, J. J., \& Sioutas, C. (2009). Size-segregated inorganic and organic components of PM in the communities of the Los Angeles Harbor. Aerosol Science and Technology, 43, 145-160.

Birmili, W., Allen, A. G., Bary, F., \& Harrison, R. M. (2006). Trace metal concentrations and water solubility in sizefractionated atmospheric particles and influence of road traffic. Environmental Science \& Technology, 40, 1144-1153.

Byrd, T., Stack, M., \& Furey, A. (2010). The assessment of the presence and main constituents of particulate matter ten microns (PM10) in Irish, rural and urban air. Atmospheric Environment, 44, 75-87.

Chen, B., Stein, A. F., Maldonado, P. G., Sanchez de la Campa, A. M., Gonzalez-Castanedo, Y., Castell, N., \& de la Rosa, J. D. (2013). Size distribution and concentrations of heavy metals in atmospheric aerosols originating from industrial emissions as predicted by the HYSPLIT model. Atmospheric Environment, 71, 234-244.

Chow, J. C. (1995). Measurement methods to determine compliance with ambient air quality standards for suspended particles. Journal of Air and Waste Management Association, 45(5), 320-382.

Contini, D., Genga, A., Cesari, D., Siciliano, M., Donateo, A., Bove, M. C., \& Guascito, M. R. (2010). Characterisation and soruce apportionment of PM10 in an urban background site in Lecce. Atmospheric Research, 95, 40-54.

Costa, D. L., \& Dreher, K. L. (1997). Bioavailable transition metals in particulate matter mediate cardiopulmonary injury in healthy and compromised animal models. Environmental Health Perspectives, 105, 1053-1060.

Cuccia, E., Piazzalunga, A., Bernardoni, V., Brambilla, L., Fermo, P., Massabò, D., Molteni, U., Prati, P., Valli, G., \& Vecchi, R. (2011). Carbonate measurements in PM10 near the marble quarries of Carrara (Italy) by infrared spectroscopy (FT-IR) and source apportionment by positive matrix factorization (PMF). Atmospheric Environment, 45, 6481-6487. 
Cuccia, E., Massabò, D., Ariola, V., Bove, M. C., Fermo, P., Piazzalunga, A., \& Prati, P. (2013). Size-resolved comprehensive characterization of airborne particulate matter. Atmospheric Environment, 67, 14-26.

Czechowski, P. O. (2009). Mechanizmy oceny jakości danych pomiarowych w koncepcji systemu analitycznego Eco Data Miner. Gdańsk: Institute of Maritime Transport and Seaborne Trade [in Polish].

Daher, N., Ruprecht, A., Invernizzi, G., De Marco, C., MillerSchulze, J., Bae Heo, J., Shafer, M. M., Shelton, B. R., Schauer, J. J., \& Sioutas, C. (2012). Characterization, sources and redox activity of fine and coarse particulate matter in Milan, Italy. Atmospheric Environment, 49, 130-141.

Daher, N., Saliba, N., Shihadeh, A. L., Jaafar, M., Baalbaki, R., Shafer, M. M., Schauer, J. J., \& Sioutas, C. (2014). Oxidative potential and chemical speciation of size-resolved particulate matter (PM) at near-freeway and urban background sites in the greater Beirut area. Science of the Total Environment, 470-471, 417-426.

Dias da Silva, L. I., de Souza Sarkis, J. E., Zanon Zotin, F. M., Castro Carneiro, M., Neto, A. A., dos Santos, A. G., da Silva, M. J., Baldini Cardoso, M. I., \& Monteiro, C. (2008). Traffic and catalytic converter-related atmospheric contamination in the metropolitan region of the city of Rio de Janeiro, Brazil. Chemosphere, 71, 677-684.

Dongarrà, G., Manno, E., Varrica, D., \& Vultaggio, M. (2007). Mass levels, crlustal component and trace elements in PM10 in Palermo, Italy. Atmospheric Environment, 41, 7977-7986.

Dreher, K. L. (2000). Particulate matter physicochemistry and toxicology: in search of causality - a critical perspective. Inhalation Toxicology, 12, 45-57.

Duvall, R. M., Majestic, B. J., Shafer, M. M., Chuang, P. Y., Simoneit, B. R. T., \& Schauer, J. J. (2008). The watersoluble fraction of carbon, sulfur, and crustal elements in Asian aerosols and Asian soils. Atmospheric Environment, $42,5872-5884$.

EC (2008). Directive 2008/50/EC of the European Parliament and of the Council of 21 May 2008 on ambient air quality and cleaner air for Europe.

Fernández-Camacho, R., Rodríguez, S., de la Rosa, J., Sánchez de la Campa, A. M., Alastuey, A., Querol, X., González-Castanedo, Y., Garcia-Orellana, I., \& Nava, S. (2012). Ultrafine particle and fine trace metal (As, $\mathrm{Cd}, \mathrm{Cu}, \mathrm{Pb}$ and $\mathrm{Zn}$ ) pollution episodes induced by industrial emissions in Huelva, SW Spain. Atmospheric Environment, 61, 507-517.

Garg, B. D., Cadle, S. H., Mulawa, P. A., \& Groblicki, P. J. (2000). Brake wear particulate matter emissions. Environmental Science \& Technology, 34, 4463-4469.

Gaudry, A., Moskura, M., Mariet, C., Ayrault, S., Denayer, F., \& Bernard, N. (2008). Inorganic pollution in PM10 particles collected over three French sites under various influences: rural conditions, traffic and industry. Water, Air, and Soil Pollution, 193, 91-106.

Geller, M. D., Ntziachristos, L., Mamakos, A., Samaras, Z., Schmitz, D. A., Froines, J. R., \& Sioutas, C. (2006). Physicochemical and redox characteristics of particulate matter (PM) emitted from gasoline and diesel passenger cars. Atmospheric Environment, 40, 6988-7004.

Gianini, M. F. D., Gehrig, R., Fischer, A., Ulrich, A., Wichser, A., \& Hueglin, C. (2012). Chemical composition of PM10 in
Switzerland: an analysis for 2008/2009 and changes since 1998/1999. Atmospheric Environment, 54, 97-106.

Gu, J., Pitz, M., Schnelle-Kreis, J., Diemer, J., Reller, A., Zimmermann, R., Soentgen, J., Stoelzel, M., Wichmann, H.-E., Peters, A., \& Cyrys, J. (2011). Source apportionment of ambient particles: comparison of positive matrix factorization analysis applied to particle size distribution and chemical composition data. Atmospheric Environment, 45, 18491857.

Harrison, R. M., \& Yin, J. (2000). Particulate matter in the atmosphere: which particle properties are important for its effects on health? Atmospheric Environment, 249, 85-101.

Harrison, R. M., Jones, A., Gietl, J., Yin, J., \& Green, D. (2012). Estimation of the contribution of brake dust, tire wear and resuspension to nonexhaust traffic particles derived from atmospheric measurements. Environmental Science \& Technology, 46, 6523-6529.

Hinds, W. C. (1998). Aerosol technology. Properties, behavior, and measurement of airborne particles (2nd ed.). New York: Wiley.

Hopke, P. K., Gladney, E. S., Gordon, G. E., Zoller, W. H., \& Jones, A. G. (1976). The use of multivariate analysis to identify sources of selected elements in the Boston urban aerosol. Atmospheric Environment, 10, 1015-1025.

Infante, R., \& Acosta, I. L. (1990). Size distribution of trace metals in Ponce, Puerto Rico air particulate matter. Atmospheric Environment, 25B, 121-131.

Juda-Rezler, K., Reizer, M., \& Oudinet, J.-P. (2011). Determination and analysis of $\mathrm{PM}_{10}$ source apportionment during episodes of air pollution in Central Eastern European urban areas: the case of wintertime 2006. Atmospheric Environment, 45, 6557-6566.

Karanasiou, A., Moreno, T., Amato, F., Lumbreras, J., Narros, A., Borge, R., Tobías, A., Boldo, E., Linares, C., Pey, J., Reche, C., Alastuey, A., \& Querol, X. (2011). Road dust contribution to PM levels - evaluation of the effectiveness of street washing activities by means of positive matrix factorization. Atmospheric Environment, 45, 2193-2201.

Kleinbaum, D. G., Kupper, L.L., Nizam, A., \& Muller, K. E. (1998). Applied regression analysis and other multivariable. Duxbury Press.

Klejnowski, K., Krasa, A., \& Rogula, W. (2007). Seasonal variability of concentrations of total suspended particles (TSP) as well as PM10, PM2.5 and PM1 modes in Zabrze, Poland. Archives of Environmental Protection, 33, 15-29.

Klejnowski, K., Pastuszka, J. S., Rogula-Kozłowska, W., Talik, E., \& Krasa, A. (2012). Mass size distribution and chemical composition of the surface layer of summer and winter airborne particles in Zabrze, Poland. Bulletin of Environmental Contamination and Toxicology, 88, 255-259.

Kong, S., Ji, Y., Lu, B., Bai, Z., Chen, L., Han, B., \& Li, Z. (2012). Chemical compositions and sources of atmospheric PM10 in heating, non-heating and sand periods at a coal-based city in northeastern China. Journal of Environmental Monitoring, 14, 852-865.

Kumar, P., Fennell, P., \& Britter, R. (2008). Measurement of particles in the 5-1000 nm range close to road level in an urban street canyon. Science of the Total Environment, 390, 437-447.

Kumar, P., Pirjola, L., Ketzel, M., \& Harrison, R. M. (2013). Nanoparticle emissions from 11 non-vehicle exhaust sources - a review. Atmospheric Environment, 67, 252-277. 
Kupiainen, K., Tervahattu, H., Raisanen, M., Makela, T., Aurela, M., \& Hillamo, R. (2005). Size and composition of airborne particles from pavement wear, tires, and traction sanding. Environmental Science \& Technology, 39, 699-706.

Larose, D. T. (2012). Methods and models for data exploration. Poland: PWN Warsaw [in Polish].

Lee, B. K., \& Lee, C. H. (2008). Analysis of acidic components, heavy metals and PAHS of particulate in the ChangwonMasan area of Korea. Environmental Monitoring and Assessment, 136, 21-33.

Lettino, A., Caggiano, R., Fiore, S., Macchiato, M., Sabia, S., \& Trippetta, S. (2012). Eyjafjallajökull volcanic ash in southern Italy. Atmospheric Environment, 48, 97-103.

Lewandowska, A. U., \& Falkowska, L. M. (2013). High concentration episodes of PM10 in the air over the urbanized coastal zone of the Baltic Sea (Gdynia-Poland). Atmospheric Research, 120, 55-67.

López-Villarrubia, E., Iñiguez, C., Peral, N., García, M. D., \& Ballester, F. (2012). Characterizing mortality effects of particulate matter size fractions in the two capital cities of the Canary Islands. Environmental Research, 112, 129-138.

Majewski, G., Kleniewska, M., \& Brandyk, A. (2011). Seasonal variation of particulate matter mass concentration and content of metals. Polish Journal of Environmental Studies, 20, 417427.

Maricq, M. M. (2007). Chemical characterization of particulate emission from diesel engines: a review. Aerosol Science, 38, 1079-1118.

Minguillón, M. C., Schembari, A., Triguero-Mas, M., de Nazelle, A., Dadvand, P., Figueras, F., Salvado, J. A., Grimalt, J. O., Nieuwenhuijsen, M., \& Querol, X. (2012). Source apportionment of indoor, outdoor and personal PM2.5 exposure of pregnant women in Barcelona, Spain. Atmospheric Environment, 59, 426-436.

Mogo, S., Cachorro, V. E., \& de Frutos, A. M. (2005). Morphological, chemical and optical absorbing characterization of aerosols in the urban atmosphere of Valladolid. Atmospheric Chemistry and Physics, 5, 2739-2748.

Molina, M. J., \& Molina, L. T. (2004). Megacities and atmospheric pollution. Journal of the Air \& Waste Management Association, 54, 644-680.

Moreno, T., Jones, T. P., \& Richards, R. J. (2004). Characterization of aerosol particulate matter from urban and industrial environments: examples from Cardiff and Port Talbot, South Wales, UK. Science of the Total Environment, 334-335, 337-346.

Moroni, B., Cappelletti, D., Marmottini, F., Scardazza, F., Ferrero, L., \& Bolzacchini, E. (2012). Integrated single particle-bulk chemical approach for the characterization of local and long range sources of particulate pollutants. Atmospheric Environment, 50, 267-277.

Na, K., \& Cocker, D. R., III. (2009). Characterization and source identification of trace elements in PM2.5 from Mira Loma, Southern California. Atmospheric Research, 93, 793-800.

Nidzgorska-Lencewicz, J., \& Czarnecka, M. (2014). Winter weather conditions vs. air quality in Tricity, Poland. Theoretical and Applied Climatology, 119, 611-627.

Pant, P., \& Harrison, R. M. (2013). Estimation of the contribution of road traffic emissions to particulate matter concentrations from field measurements: a review. Atmospheric Environment, 77(2013), 78-97.
Pastuszka, J. S. (1997). Study of PM-10 and PM-2.5 concentrations in Southern Poland. Journal of Aerosol Science, 28(Suppl.1), 227-228.

Pastuszka, J. S., Wawroś, A., Talik, E., \& Paw, U. K. T. (2003). Optical and chemical characteristics of the atmospheric aerosol in four towns in southern Poland. Science of the Total Environment, 309, 237-251.

Pastuszka, J. S., Rogula-Kozłowska, W., \& Zajusz-Zubek, E. (2010). Characterization of PM10 and PM2,5 and associated heavy metals at the crossroads and urban background site in Zabrze, Upper Silesia, Poland, during the smog episodes. Environmental Monitoring and Assessment, 168, 613-627.

Pope, C. A., \& Dockery, D. W. (2006). Health effects of fine particulate air pollution: lines that connect. Journal of the Air \& Waste Management Association, 56, 709-742.

Pope, C. A., Burnett, R. T., Thun, M. J., Calle, E. E., Krewski, D., Ito, K., \& Thurston, G. D. (2002). Lung cancer, cardiopulmonary mortality, and long-term exposure to fine particulate air pollution. The Journal of the American Medical Association, 287, 1132-1141.

Querol, X., Viana, M., Alastuey, A., Amato, F., Moreno, T., Castillo, S., Pey, J., Rosa, J., Campa, A. S., Artínano, B., Salvador, P., Santos, S. G., Fernández-Patier, R., MorenoGrau, S., Negral, L., Minguillón, M. C., Monfort, E., Gil, J. I., Inza, A., Ortega, L. A., Santammaría, J. M., \& Zabalza, J. (2007). Source origin of trace elements in PM from regional background, urban and industrial sites of Spain. Atmospheric Environment, 41, 7219-7231.

Rogula-Kozłowska, W., Kozielska, B., Błaszczak, B., \& Klejnowski,K. (2012). The Mass Distribution of ParticleBound PAH Among Aerosol Fractions: A Case-Study of an Urban Area in Poland In T. Puzyn, \& A. Mostrag-Szlichtyng (Eds.), Organic pollutants ten years after the Stockholm convention - environmental and analytical update. InTech (ISBN 978-953-307-917-2).

Rogula-Kozłowska, W., Błaszczak, B., Szopa, S., Klejnowski, K., Sówka, I., Zwoździak, A., Jabłońska, M., \& Mathews, B. (2013a). PM2.5 in the central part of Upper Silesia, Poland: concentrations, elemental composition, and mobility of components. Environmental Monitoring and Assessment, 185, 581-601.

Rogula-Kozłowska, W., Kozielska, B., Klejnowski, K., \& Szopa, S. (2013b). The hazardous compounds in urban PM in the central part of Upper Silesia (Poland) in Winter. Archives of Environmental Protection, 39, 53-65.

Rogula-Kozłowska, W., Klejnowski, K., Rogula-Kopiec, P., Błaszczak, B., Mathews, B., \& Szopa, S. (2013c). Mass size distribution of PM-bound elements at an urban background site: results of an eight-month study in Zabrze. Rocznik Ochrona Środowiska (Annual Set Protection), 15, 1022-1040.

Rogula-Kozłowska, W., Klejnowski, K., Rogula-Kopiec, P., Ośródka, L., Krajny, E., Błaszczak, B., \& Mathews, B. (2014). Spatial and seasonal variability of the mass concentration and chemical composition of PM2.5 in Poland. Air Quality, Atmosphere \& Health, 7, 41-58.

Saldiva, P. H. N., Clarke, R. W., Coull, B. A., Stearns, R. C., Lawrence, J., Murthy, G. G. K., Diaz, E., Koutrakis, P., Suh, H., Tsuda, A., \& Godleski, J. J. (2002). Lung inflammation induced by concentrated ambient air particles is related to particle composition. American Journal of Respiratory and Critical Care Medicine, 165, 1610-1617. 
Sánchez-Jiménez, A., Heal, M. R., \& Beverland, I. J. (2012). Correlations of particle number concentrations and metals with nitrogen oxides and other traffic-related air pollutants in Glasgow and London. Atmospheric Environment, 54, 667-678.

Sanderson, P., Delgado Saborit, J. M., \& Harrison, R. M. (2014). A review of chemical and physical characterization of atmospheric metallic nanoparticles. Atmospheric Environment, 94, 353365.

Seinfeld, J. H., \& Pandis, S. N. (1998). Atmospheric chemistry and physics: from air pollution to climate change. New York: Wiley.

Slezakowa, K., Pereira, M. C., Reis, M. A., \& Alvim-Ferraz, M. C. (2007). Influence of traffic on the composition of atmospheric particles of different sizes-Part 1: concentrations and elemental characterization. Journal of Atmospheric Chemistry, 58, 55-68.

Sówka, I., Zwoździak, A., Trzepla-Nabaglo, K., Skrętowicz, M., \& Zwoździak, J. (2012). PM2.5 elemental composition and source apportionment in a residential area of Wrocław, Poland. Environment Protection Engineering, $38,73-79$.

Sternbeck, J., Sjödin, Å., \& Andréasson, K. (2002). Metal emissions from road traffic and the influence of resuspensionresults from two tunnel studies. Atmospheric Environment, $36,4735-4744$.

Szoboszlai, Z., Kertész, Z., Szikszai, Z., Angyal, A., Furu, E., Török, Z., Daróczi, L., \& Kiss, Á. Z. (2012). Identification and chemical characterization of particulate matter from wave soldering processes at a printed circuit board manufacturing company. Journal of Hazardous Materials, 203-204, 308-316.

Tecer, L. H., Tuncel, G., Karaca, F., Alagha, O., Süren, P., Zarasiz, A., \& Kirmaz, R. (2012). Metallic composition and source apportionment of fine and coarse particles using positive matrix factorization in the southern Black Sea atmosphere. Atmospheric Research, 118, 153-159.

Theodosi, C., Im, U., Bougiatioti, A., Zarmpas, P., Yenigun, O., \& Mihalopoulos, N. (2010). Aerosol chemical composition over Istanbul. Science of the Total Environment, 408, 24822491.

Thurston, G. D., \& Spengler, J. D. (1985). A quantitative assessment of source contributions to inhalable particulate matter pollution in metropolitan Boston. Atmospheric Environment, 19, 9-25.

Vercauteren, J., Matheeussen, C., Wauters, E., Roekens, E., van Grieken, R., Krata, A., Makarovska, Y., Maenhaut, W., Chi, X., \& Geypens, B. (2011). Chemkar PM10: an extensive look at the local differences in chemical composition of PM10 in Flanders, Belgium. Atmospheric Environment, 45, 108-116.

Wahlin, P., Berkowicz, R., \& Palmgren, F. (2006). Characterisation of traffic-generated particulate matter in Copenhagen. Atmospheric Environment, 40, 2151-2159.

Wedepohl, K. H. (1995). The composition of the continental crust. Geochimica et Cosmochimica Acta, 59, 1217-1232.

Wellenius, G. A., Coull, B. A., Godleski, J. J., Koutrakis, P., Okabe, K., Savage, S. T., Lawrence, J. E., Murthy, G. G. K., \& Verrier, R. L. (2003). Inhalation of concentrated ambient air particles exacerbates myocardial ischemia in conscious dogs. Environmental Health Perspectives, 111, 402408.

Whitby, K. J. (1978). The physical characteristics of sulfur aerosol. Atmospheric Environment, 12, 135-139.

Whitby, E. R., \& McMurry, P. H. (1997). Modal aerosol dynamics modeling. Aerosol Science and Technology, 27, 673-688.

WHO. (2000). WHO Air Quality Guidelines for Europe, 2000. WHO Regional Publications Eur. Ser. No. 91. Copenhagen: Regional Office for Europe.

Witt, M. L. I., Meheran, N., Mather, T. A., de Hoog, J. C. M., \& Pyle, D. M. (2010). Aerosol trace metals, particle morphology and total gaseous mercury in the atmosphere of Oxford, UK. Atmospheric Environment, 44, 1524-1538.

Zwoździak, A., Sówka, I., Krupińska, B., Zwoździak, J., \& Nych, A. (2013). Infiltration or indoor sources as determinants of the elemental composition of particulate matter inside a school in Wrocław, Poland? Building and Environment, 66, 173-180. 